\title{
A geochemical approach to reconstruct modern dust fluxes and sources to the South Pacific
}

\author{
Marc Wengler ${ }^{\mathrm{a}, \mathrm{b}, *}$, Frank Lamy ${ }^{\mathrm{a}, \mathrm{b}}$, Torben Struve ${ }^{\mathrm{c}}$, Alejandra Borunda ${ }^{\mathrm{d}}$ \\ Philipp Böning ${ }^{c}$, Walter Geibert ${ }^{a}$, Gerhard Kuhn ${ }^{a}$, Katharina Pahnke ${ }^{c}$ \\ Jenny Roberts ${ }^{\mathrm{a}}$, Ralf Tiedemann ${ }^{\mathrm{a}}$, Gisela Winckler ${ }^{\mathrm{d}}$ \\ a Alfred Wegener Institute, Helmholtz Center for Polar and Marine Research, Department for Marine Geology, D-27515 Bremerhaven, Germany \\ ${ }^{\mathrm{b}}$ MARUM Center for Marine Environmental Sciences, University of Bremen, D-28334 Bremen, Germany \\ ${ }^{\mathrm{c}}$ Marine Isotope Geochemistry, Institute for Chemistry and Biology of the Marine Environment (ICBM), University of Oldenburg, \\ D-26129 Oldenburg, Germany \\ d Lamont-Doherty Earth Observatory, Columbia University, Palisades, 10964 New York, USA
}

Received 10 November 2017; accepted in revised form 19 August 2019; Available online 26 August 2019

\begin{abstract}
We present the first comprehensive dust provenance and lithogenic flux data set extracted from surface sediments distributed across the polar and subpolar South Pacific. The dataset comprises ${ }^{230} \mathrm{Th}$-normalized lithogenic fluxes combined with rare earth elements, strontium, neodymium and lead isotope data to determine lithogenic fluxes, spatial distribution and sources of dust $(<10 \mu \mathrm{m})$ during the Holocene. We observe the highest lithogenic fluxes in surface sediments near New Zealand which most likely indicate a combination of Australian dust and riverine input from New Zealand. Similarly, high fluxes off West Antarctica are ascribed to sediment input from the nearby continental shelf and margin. In contrast, the lithogenic fluxes in the remote open ocean are derived from dust input. Isotopic and REE data suggest that the Lake Eyre Basin in central Australia is the most prominent potential source area for dust distributed over the South Pacific during the Holocene, with additional input from the Darling Basin in southeast Australia.
\end{abstract}

(C) 2019 Elsevier Ltd. All rights reserved.

Keywords: South Pacific; Modern dust provenance; Lithogenic fluxes; Rare earth elements; Radiogenic isotopes

\section{INTRODUCTION}

Several studies have shown that dust plays a crucial role in modulating the global climate system (e.g. Tegen and Fung, 1994; Kohfeld and Harrison, 2001; Jickells et al., 2005). Dust either impacts the climate directly, by influencing the radiative properties of the atmosphere through scattering and absorbing light, or indirectly, by modifying

\footnotetext{
* Corresponding author at: Alfred Wegener Institute, Helmholtz Center for Polar and Marine Research, Department for Marine Geology, D-27515 Bremerhaven, Germany.

E-mail address: marc.wengler@awi.de (M. Wengler).
}

cloud properties (Arimoto, 2001; Sassen et al., 2003). Furthermore, dust is capable of influencing the climate through its effect on surface ocean productivity. According to the iron hypothesis (Martin, 1990), elevated dust fluxes to the ocean can enhance the marine productivity in highnutrient low-chlorophyll regions, such as the Southern Ocean, resulting in a drawdown of atmospheric $\mathrm{CO}_{2}$. High-resolution dust records from the Southern Ocean seem to support the iron hypothesis, indicating higher dust deposition rates coupled with higher export productivity in glacial periods compared to interglacial periods (Chase et al., 2003; Bradtmiller et al., 2009; Martínez-Garcia 
et al., 2009; Martínez-Garcia et al., 2011; Martínez-García et al., 2014; Lamy et al., 2014).

Current knowledge about the distribution of dust in the Southern Hemisphere is largely based on modeling studies (Mahowald et al., 2006; Maher et al., 2010; Albani et al., 2014; Neff and Bertler, 2015) and suggests Australia/New Zealand as predominant source of dust to the Pacific sector of the Southern Ocean (e.g. Prospero et al., 2002; Li et al., 2008; Ginoux et al., 2012). However, no field studies on the provenance and lithogenic fluxes of dust exist so far from the southern South Pacific, the largest sector of the Southern Ocean.

In the ocean, the particle reactive element thorium is produced at a constant rate due to the decay of highly soluble uranium. Attached to sinking particles thorium is transported to the seafloor where it can be measured as "thorium excess" (Bacon, 1984; Thomson et al., 1993; Francois et al., 2004). Based on this concept, we reconstruct the spatial accumulation of lithogenic material in the Pacific sector of the Southern Ocean using the ${ }^{230} \mathrm{Th}$ normalization method (Bacon, 1984; Thomson et al., 1993; Francois et al., 2004). Furthermore, we measured provenance-sensitive proxies, including rare earth elements (REE), strontium $(\mathrm{Sr})$, neodymium $(\mathrm{Nd})$ and lead $(\mathrm{Pb})$ isotopes from the lithogenic fine fraction $(<10 \mu \mathrm{m})$ of marine surface sediments to determine the provenance of dust to the Pacific sector of the Southern Ocean. The concept of using radiogenic isotopes and REE concentrations in the lithogenic fraction of marine sediment samples as provenance tracers is based on their specific signatures in rocks of different lithology and age, allowing the differentiation of potential dust source areas (e.g. Grousset and Biscaye, 2005). Our results show that the radiogenic isotopes clearly discriminate between Australian sources, whereas the use of REE enables us to effectively exclude New Zealand as a potential source of dust to the Pacific Southern Ocean. Therefore, coupled analysis of radiogenic isotopes and REE is a valuable tool to identify the dust provenance.

\section{SETTING OF POTENTIAL SOURCE AREAS TO THE SOUTH PACIFIC}

\subsection{Australia}

The Lake Eyre Basin in central Australia is the most active dust storm area on the continent (McTainsh, 1989) (Fig. 1). Dust activity in the Lake Eyre Basin may occur anytime throughout the year, with highest dust entrainment activities during late spring and early summer (September December), when precipitation rates are lowest (Ekström et al., 2004). Dust entrainment in the Lake Eyre Basin needs favorable atmospheric conditions, such as the presence of

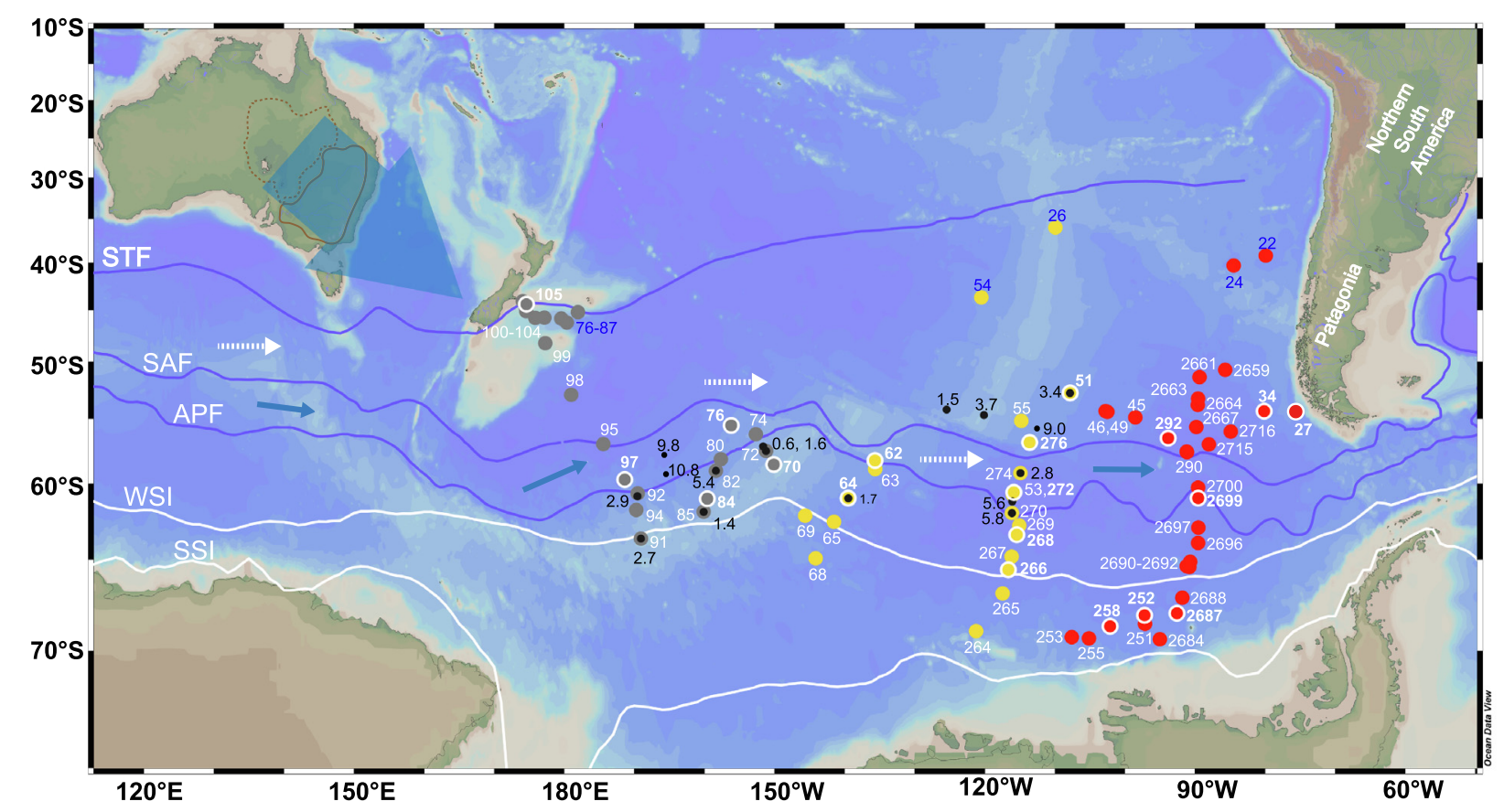

Fig. 1. Map of the South Pacific with locations of surface samples recovered during R/V Polarstern (white numbers) and R/V Sonne (blue numbers) expeditions. White and blue numbers attached to the sampling locations refer to the station numbers. Gray dots: Western South Pacific, yellow dots: Central South Pacific, red dots: Eastern South Pacific. The white outline and bold numbers highlight the samples that were used for provenance analyses. Small black dots highlight sediment cores with age models (Benz et al., 2016). Black numbers illustrate the core top age in kyrs, see Benz et al. (2016) for detailed information about the age models. Colored lines indicate the mean positions of major frontal systems (Orsi et al., 1995). STF: Subtropical Front, SAF: Subantarctic Front, APF: Antarctic Polar Front. Mean extension of winter and summer sea ice (WSI and SSI) is indicated by white lines. Blue arrows indicate the flow direction of the Antarctic Circumpolar Current. White dashed arrows show the direction of the Southern Westerly Winds. The dashed brown line encircles the Lake Eyre Basin. The solid brown line encircles the Murray-Darling Basin. The large blow arrow indicates the dust transport direction. The map was generated using the Ocean Data View software (Schlitzer, 2015). (For interpretation of the references to colour in this figure legend, the reader is referred to the web version of this article.) 
sub-tropical cold fronts (Tsoar and Pye, 1987; McGowan and Clark, 2008). The rivers in the northeast sector of the Lake Eyre Basin contribute the largest amounts of sediment load into the lower parts of the basin (McTainsh, 1989).

The Murray-Darling Basin in southeast Australia represents the largest river system on the continent (McTainsh, 1989; De Deckker et al., 2010; Marx and Kamber, 2010) (Fig. 1). Due to the geographical extent of the MurrayDarling Basin it experiences different rainfall seasonality. The Darling river is predominantly fed by summer rainfall originating in southeast Queensland and northern New South Wales, whereas winter rainfall in the Snowy Mountains is the main source for the Murray river (McTainsh, 1989). The Murray-Darling Basin is affected by seasonal flooding events leading to the accumulation of fine sediments in the floodplains of the basin which are vulnerable to dust entrainment (McTainsh, 1989). Therefore, the Murray-Darling basin is an important source of modern dust.

After dust entrainment, long-range dust transport from both areas follows the southeast dust transport corridor, which describes the major dust transport direction over southeast Australia (Fig. 1) (Bowler, 1976; McGowan and Clark, 2008). Based on sediment cores from the Tasman Sea and their dust fluxes it was shown that the northern margin of the corridor migrates between $33^{\circ} \mathrm{S}$ and $36.2^{\circ} \mathrm{S}$ in interglacial periods and between $33^{\circ} \mathrm{S}$ and $30.33^{\circ} \mathrm{S}$ in glacial stages (Hesse, 1994). The center of the dust transport corridor is always located between $36.29^{\circ} \mathrm{S}$ and $42^{\circ} \mathrm{S}$ (Hesse and McTainsh, 2003), after which the southern westerly wind belt (SWW) continue to transport the dust across the Southern Ocean (Fig. 1).

\subsection{New Zealand}

The New Zealand climate is significantly affected by the northeast to southwest orientated Southern Alps. The large loess areas at the west coast of the South Island were supplied from the Southern Alps during Quaternary coldclimate processes (e.g. freeze/thaw and glacial grinding) (Eden and Hammond, 2003). Because New Zealand is predominately under the influence of the prevailing SWW, the loess areas on the South Island likely act as a potential source area (PSA).

\section{METHODS}

\subsection{Sample selection}

We analyzed sediment surface samples from across the Pacific sector of the Southern Ocean recovered during expeditions with R/V Polarstern (PS35, PS58, PS75, PS97) (Gersonde, 1995; Gersonde, 2001; Gersonde, 2011; Lamy, 2016) and R/V Sonne (SO213) (Tiedemann, 2012) (Fig. 1). All samples were collected with a multicorer between $39^{\circ} \mathrm{S}$ to $70^{\circ} \mathrm{S}$ and $175^{\circ} \mathrm{E}$ to $80^{\circ} \mathrm{W}$. Within this longitudinal range, the study area is subdivided into western $\left(175^{\circ} \mathrm{E}\right.$ to $\left.150^{\circ} \mathrm{W}\right)$, central $\left(145^{\circ} \mathrm{W}\right.$ to $\left.107^{\circ} \mathrm{W}\right)$ and eastern parts $\left(105^{\circ} \mathrm{W}\right.$ to $\left.80^{\circ} \mathrm{W}\right)$ (Fig. 1). Our sample sites extend across the Antarctic Circumpolar Current from the Antarc- tic Zone south of the winter sea-ice margin, across the Polar Frontal Zone into the Subantarctic Zone (Fig. 1). Lithogenic fluxes were determined on the bulk sediment of 74 surface samples using the ${ }^{230} \mathrm{Th}$ normalization method (Francois et al., 2004) (Fig. 2). Provenance analysis, including $\mathrm{REE}$ concentrations, $\mathrm{Sr}, \mathrm{Nd}$ and $\mathrm{Pb}$ isotopes were performed on the $<10 \mu \mathrm{m}$ fraction of 19 sediment surface samples (Fig. 1). The surface samples are assumed to be representative of the Holocene because they are closely located to sediment cores that have core top ages of $<11$ kyrs BP (Fig. 1) (Benz et al., 2016). We selected the $<10 \mu \mathrm{m}$ fraction, because this fraction is typically considered resistant to sediment redistribution by bottom currents (McCave et al., 1995). Additionally, we measured Sr and $\mathrm{Nd}$ isotopes using the $<5$ fraction of 5 selected samples from our data set to evaluate potential grain size effects.

\subsection{Uranium - thorium methodology}

The ${ }^{230} \mathrm{Th}$ isotope is a product of the ${ }^{238} \mathrm{U}$ decay series with a half-life of $75.548 \pm 110$ years (Cheng et al., 2013). The parent isotope ${ }^{234} \mathrm{U}$ produces (through $\alpha$-decay) the highly insoluble (in seawater) and particle reactive ${ }^{230} \mathrm{Th}$ isotope at a uniform and well-known rate $(\beta=0.0267$ $\mathrm{dpm} \mathrm{m}^{-3}$ year $\left.{ }^{-1}\right)$. Attached to sinking particles, ${ }^{230} \mathrm{Th}$ is transported to the seafloor (Thomson et al., 1993; Francois et al., 2004). Sediment particles are assumed to contain a fraction of ${ }^{230} \mathrm{Th}$ in a secular equilibrium with lithogenic ${ }^{234} \mathrm{U}$. However, the total amount of ${ }^{230} \mathrm{Th}$ in deep-sea sediments near the sediment surface exceeds the amount supported by ${ }^{234} \mathrm{U}$. This fraction of ${ }^{230} \mathrm{Th}$ is called ${ }^{230} \mathrm{Th}_{\mathrm{xs}}$ (230-Thorium excess) (Francois et al., 2004). This relationship forms the basis for the ${ }^{230} \mathrm{Th}$ normalization method (Thomson et al., 1993). To determine the concentrations of $\mathrm{Th}$ and $\mathrm{U}$ isotopes, approximately $50 \mathrm{mg}$ of freeze-dried bulk sediment was spiked with known amounts of ${ }^{229} \mathrm{Th}$ and ${ }^{236} \mathrm{U}$. The sediment was digested in a CEM Mars X-press microwave system in $2 \mathrm{~mL}$ concentrated $\mathrm{HCl}, 3 \mathrm{~mL}$ concentrated $\mathrm{HNO}_{3}$ and $0.5 \mathrm{~mL} \mathrm{HF} 40 \%$ (suprapur $^{\circledR}$ ). The resulting solution was evaporated to near dryness using the microwave XVap accessory and redissolved in $1 \mathrm{M} \mathrm{HNO}_{3}$ in the microwave system. Three consecutive steps of iron precipitation were then applied to separate $\mathrm{Th}$ and $\mathrm{U}$ isotopes from the sample matrix. The precipitate that contained $\mathrm{Th}$ and $\mathrm{U}$ was dissolved in $3 \mathrm{M}$ $\mathrm{HNO}_{3}$ and passed through equilibrated $2 \mathrm{~mL}$ columns filled with Eichrom UTEVA resin for separation of Th and $U$ isotopes from iron. Th and $U$ isotopes were measured separately by sector-field ICP-MS (Thermo Fisher Element 2 equipped with an ESI Apex desolvation nebulizer) in lowresolution mode. External reproducibility was monitored using a certified reference material (UREM 11) and procedural blanks were run alongside the samples. All chemical and analytical processing, including digestion, ion exchange chromatography and mass spectrometric analyses was carried out at the Alfred Wegener Institute in Bremerhaven (AWI). Corrections for tailing from ${ }^{232} \mathrm{Th}\left({ }^{238} \mathrm{U}\right)$, mass bias and procedural blanks were applied as appropriate and considered in the error propagation. Propagated analytical uncertainties of ${ }^{230} \mathrm{Th}_{\mathrm{xs}}$ for this method are less than $5 \%$ 


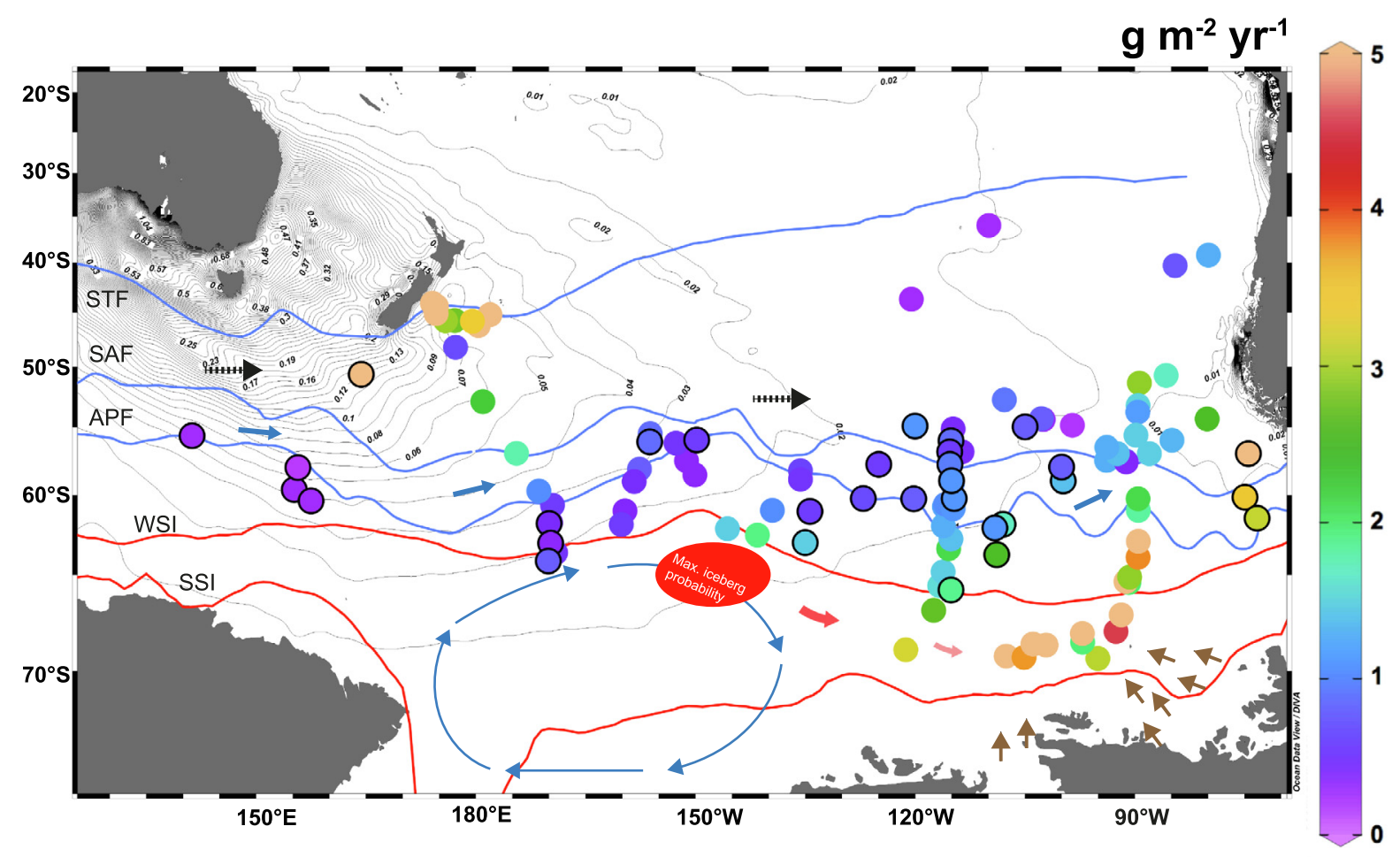

Fig. 2. Spatial distribution of ${ }^{230} \mathrm{Th}$-normalized lithogenic fluxes in the study area in $\mathrm{g} \mathrm{m}^{-2} \mathrm{yr}^{-1}$. Blue lines mark the mean positions of major frontal systems (Orsi et al., 1995). STF: Subtropical Front, SAF: Subantarctic Front, APF: Antarctic Polar Front. Mean extension of winter and summer sea ice (WSI and SSI) is indicated by red lines. Thin blue arrows illustrate the Ross Gyre (Assmann et al., 2005). Dashed black arrows indicate the Southern Westerly Winds. Thick blue arrows indicate the flow direction of the Antarctic Circumpolar Current. Brown arrows indicate terrigenous sediment input in the flat Bellingshausen abyssal plain (Rebesco et al., 1996; Hillenbrand, 2000). Red shaded area refers to the maximum iceberg probability with eastward decreasing abundances indicated by red arrows with fading colors (Tournadre et al., 2012). Symbols with black outline show Holocene data from Chase et al. (2003) and Bradtmiller et al. (2009). Thin gray lines reveal the modern modeled dust wet deposition in $\mathrm{g} \mathrm{m}^{-2} \mathrm{yr}^{-1}$ from Albani et al. (2014). The map was generated using the Ocean Data View software (Schlitzer, 2015). (For interpretation of the references to colour in this figure legend, the reader is referred to the web version of this article.)

$(1 \sigma) .{ }^{238} \mathrm{U}$ was calculated from ${ }^{235} \mathrm{U}$ using the natural isotope abundance. Supported ${ }^{230} \mathrm{Th}$ was calculated according to Francois et al. (2004), using a ${ }^{238} \mathrm{U} /{ }^{232} \mathrm{Th}$ activity ratio of 0.4 (Henderson and Anderson, 2003). A part of the lithogenic fluxes was produced via isotope dilution alphaspectrometry at the AWI (Tab. A 4), following the methods in Walter et al. (1997). The precision of some values determined by alpha-spectrometry may be somewhat lower than those determined by ICP-MS, in particular for ${ }^{232} \mathrm{Th}$, but the isotope dilution method ensures excellent accuracy, as regularly checked by replicates of reference material and samples, and the analytical uncertainty is small compared to the variation in samples. We used ${ }^{230} \mathrm{Th}_{\mathrm{xs}}$ to calculate the preserved vertical lithogenic fluxes by multiplying the uniform ${ }^{230} \mathrm{Th}$ production rate $\left(\beta=0.267 \mathrm{dpm} \mathrm{m}^{-3} \mathrm{yr}^{-1}\right)$ and the water depth divided by the ${ }^{230} \mathrm{Th}_{\mathrm{xs}}$ concentrations $\left(\mathrm{dpm} \mathrm{g} \mathrm{g}^{-1}\right.$ ) (Francois et al., 2004; Geibert et al., 2005; Martínez-Garcia et al., 2009; Lamy et al., 2014). The ${ }^{232} \mathrm{Th}$ concentrations were used to determine the lithogenic fraction in the surface samples assuming an average ${ }^{232} \mathrm{Th}$ concentration of $10 \mathrm{ppm}$ for the upper continental crust. The lithogenic end-member of $10 \mathrm{ppm}$ for the upper continental crust was inferred from the relationship of our measured ${ }^{232} \mathrm{Th}$ concentrations versus the sum of our nonlithogenic fractions. In the following text, we refer to the sediment redistribution-corrected vertical lithogenic fluxes in short as lithogenic fluxes. The decay of ${ }^{230} \mathrm{Th}$ was considered to be insignificant because our data set exclusively uses surface samples.

\subsection{Grain size separation and leaching}

All samples selected for provenance analyses were processed through a two-step grain size separation procedure in the sediment labs at the AWI to extract the $<10$ and $<5 \mu \mathrm{m}$ (only 5 test samples) fractions from the bulk sediment samples. First, all samples were wet sieved through a $63 \mu \mathrm{m}$ mesh followed by Stokes-based separation of the target fine fraction from the $<63 \mu \mathrm{m}$ fraction using Atterberg glass settling cylinders. Reagent grade ammonia solution was added to the settling tubes to raise the $\mathrm{pH}$ to $\sim 7$ to avoid aggregation of particles.

We tested different leaching procedures at the Institute for Chemistry and Biology of the Marine Environment (ICBM) in Oldenburg with respect to their efficiency in extracting an original lithogenic signal from our marine sediment samples. Note that the samples were triplerinsed with Milli-Q water (MQ) after every leaching step. First, all surface samples were treated with $5 \% \mathrm{H}_{2} \mathrm{O}_{2}$ to remove organic material followed by an acetic acid (buf- 
fered with $\mathrm{NaOH}$ to $\mathrm{pH}=5$ ) leach to eliminate carbonate. Then, the samples were treated with $13 \mathrm{~mL}$ of $0.02 \mathrm{M}$ hydroxylamine hydrochloride $(\mathrm{HH})$ - acetic acid $(\mathrm{AcOH})$ in two consecutive steps followed by separation of the $<10 \mu \mathrm{m}$ fraction. After the separation of the $<10 \mu \mathrm{m}$ fraction, all samples were triple-rinsed with Milli-Q water (MQ) and freeze-dried. Subsamples of $\sim 50 \mathrm{mg}$ were taken from the freeze-dried fine fraction material for digestion and chemical extraction of target elements.

We selected a subset of five freeze-dried samples which were chemically treated with a second reductive $\mathrm{HH}$ $\mathrm{AcOH}$ leach as described above, but after grain size separation of the $<10 \mu \mathrm{m}$ fraction to test the efficiency of the reductive leaching protocol for removal of contaminant metal-bearing phases induced during sample preparation and grain size separation. Again, the samples were freezedried and subsamples of $\sim 50 \mathrm{mg}$ were taken for digestion and further processing. Subsequently, all residual freezedried fine fraction samples were exposed to $1 \mathrm{M} \mathrm{HCl}$ overnight, followed by an overnight exposure to $0.03 \mathrm{M}$ EDTA and a final sequence of five MQ washing steps. The samples were then freeze-dried again and subsamples of $\sim 50 \mathrm{mg}$ were taken for further sample processing.

\subsection{Chemical extraction of strontium, neodymium and lead}

All chemical and analytical sample processing including digestion and ion exchange chromatography was carried out at the ICBM in Oldenburg using either Fisher Scientific optima grade ${ }^{\mathrm{TM}}$ reagents and/or acids purified under ISO class 4-5 clean room conditions using the Savillex ${ }^{\circledR}$ DST1000 acid purification system. The external reproducibility at $95 \%$ confidence ( 2 standard deviations, 2SD) was assessed with repeated analyses of USGS rock reference materials AGV-1 and BCR-2 included in each batch of samples. Prior to digestion, $\sim 50 \mathrm{mg}$ of the freeze-dried sediment was first treated over night with aqua regia at $130{ }^{\circ} \mathrm{C}$ to destroy any remaining organic matter and followed by $\mathrm{HNO}_{3}-\mathrm{HF}$ $\mathrm{HClO}_{4}$-based pressure digestion at $180^{\circ} \mathrm{C}$ using a PicoTrace digestion block for $>12$ hours. The resulting clear solutions were dried and fumed off three times with $6 \mathrm{M} \mathrm{HCl}$ and converted to bromide form with $\mathrm{HBr}$. For REE analyses, a 10\% aliquot of the total digest was dried and taken up in $0.3 \mathrm{M}$ $\mathrm{HNO}_{3}$ in preparation for analysis. The remaining solution was then passed through a two-stage $\mathrm{HBr}-\mathrm{HNO}_{3}$-based $\mathrm{Pb}$ extraction using $100 \mu \mathrm{L}$ AG1-X8 (100-200 $\mu \mathrm{m}$ mesh) resin (after Lugmair and Galer, 1992). The alkaline earth metals including $\mathrm{Sr}$ were separated from the REE using a $\mathrm{HCl}$ based procedure with Biorad $^{\circledR}$ AG50W-X8 (200-400 $\mu \mathrm{m}$ mesh) resin (Strelow, 1960; Struve et al., 2016). Strontium was isolated from the remaining sample matrix using TrisKem Sr spec ${ }^{\circledR}$ resin (Horwitz et al., 1992) and Nd was separated from the REE using TrisKem LnSpec ${ }^{\circledR}$ chemistry (Pin and Zalduegui, 1997).

3.5. Analysis of rare earth element concentrations, strontium, neodymium and lead isotopes

All mass spectrometric analyses of REE concentrations and $\mathrm{Sr}, \mathrm{Nd}$, and $\mathrm{Pb}$ isotopes were carried out at the ICBM in Oldenburg. The REE concentrations were determined using a Thermo Finnigan Element $I I^{\mathrm{TM}}$ ICP-MS in low resolution mode using indium as an internal standard. Analytical precision and accuracy (determined by simultaneous runs of $\mathrm{AGV}-1$ and $\mathrm{BCR}-2 ; \mathrm{n}=5$ ) was better than $8 \%$ and $14 \%$ (2SD) for all elements, respectively. Procedural blanks were $\leq 1 \%$ of the signal intensity of the samples and therefore insignificant.

Radiogenic isotope compositions were determined using a multi-collector ICP-MS (Thermo Scientific Neptune Plus). For $\mathrm{Nd}$ isotope analyses, mass bias was corrected for using ${ }^{146} \mathrm{Nd} /{ }^{144} \mathrm{Nd}=0.7219$ and an exponential law yielding JNdi values of ${ }^{143} \mathrm{Nd} /{ }^{144} \mathrm{Nd}=0.512082 \pm 0.000012(2 \mathrm{SD})(\mathrm{n}=8)$ and ${ }^{143} \mathrm{Nd} /{ }^{144} \mathrm{Nd}=0.512089 \pm 0.000014(2 \mathrm{SD})(\mathrm{n}=11)$ for the two analytical sessions, respectively. The mass biascorrected ${ }^{143} \mathrm{Nd} /{ }^{144} \mathrm{Nd}$ ratios of all samples and secondary reference materials were corrected for this instrumental offset from the JNdi-1 reference ratio of $0.512115 \pm 0.000007$ (Tanaka et al., 2000). The external reproducibility (2SD) of normalized $\mathrm{Nd}$ isotope ratios of BCR-2 and AGV-1 reference material was $0.512645 \pm 0.000010(\mathrm{n}=16)$ and $0.512796 \pm 0.000017(\mathrm{n}=16)$, respectively. These results are in excellent agreement with literature values of $0.512637 \pm 0.000012$ (2SD) (Jweda et al., 2016) for acidleached BCR-2 residues and $0.512791 \pm 0.000013$ (2SD) for unleached AGV-1 rock powder (Weis et al., 2006). The sample results are expressed in epsilon notation, $\left.\varepsilon \mathrm{Nd}=\left[\left({ }^{143} \mathrm{Nd} /{ }^{144} \mathrm{Nd}\right)_{\text {sample }} /{ }^{143} \mathrm{Nd} /{ }^{144} \mathrm{Nd}\right)_{\mathrm{CHUR}}-1\right] * 10^{4}$ where CHUR is the Chondritic Uniform Reservoir (Jacobsen and Wasserburg, 1980).

For $\mathrm{Sr}$ isotope analyses, internal mass bias was corrected using ${ }^{86} \mathrm{Sr} /{ }^{88} \mathrm{Sr}=0.1194$ and an exponential law yielding ${ }^{87} \mathrm{Sr} /{ }^{86} \mathrm{Sr}=0.710270 \pm 0.000016 \quad(\mathrm{n}=11) \quad$ and ${ }^{87} \mathrm{Sr} /{ }^{86}$ $\mathrm{Sr}=0.710264 \pm 0.000012(\mathrm{n}=11)$ for two analytical sessions, respectively. The mass bias-corrected ${ }^{87} \mathrm{Sr} /{ }^{86} \mathrm{Sr}$ ratios of all samples and secondary reference materials were corrected for this instrumental offset from the reported NIST SRM ${ }^{87} \mathrm{Sr} /{ }^{86} \mathrm{Sr}$ of 0.710248 (Thirlwall, 1991). Analyses of BCR-2 $(\mathrm{n}=16)$ and AGV-1 $(\mathrm{n}=16) \mathrm{Sr}$ isotopic compositions yielded ${ }^{87} \mathrm{Sr} /{ }^{86} \mathrm{Sr}=0.704997$ and 0.703949 , while the external reproducibility (2SD) was \pm 0.000017 and \pm 0.000035 , respectively. These values are consistent with the values reported for acid-leached residues of BCR-2 $(0.705000 \pm 0.0000112 \mathrm{SD}$, Jweda et al., 2016) and AGV1 reference materials $(0.703950 \pm 0.000012$ 2SD, Weis et al., 2006). Krypton 'gas blanks' measured on ${ }^{83} \mathrm{Kr}$ used to correct for ${ }^{86} \mathrm{Kr}$ on ${ }^{86} \mathrm{Sr}$ were below $0.1 \mathrm{mV}$ (while ${ }^{86} \mathrm{Sr}$ was measured at 2-3 V).

The analyses of the $\mathrm{Pb}$ isotopic compositions were performed as standard-sample bracketing using NIST SRM 981 as bracketing standard (Albarède et al., 2004) and correcting for isobaric interference of $\mathrm{Hg}$. The mass bias of samples and certified reference materials were corrected for by normalization of the raw SRM 981 values to the literature values as reported by Galer and Abouchami (1998). The external reproducibility (2SD) of $\mathrm{Pb}$ isotope ratios for $\mathrm{BCR}-2(\mathrm{n}=15)$ was ${ }^{206} \mathrm{~Pb} /{ }^{204} \mathrm{~Pb}=18.8031$ $\pm 0.0015 \quad(18.8029 \pm 0.0010 \quad 2 \mathrm{SD}$, Jweda et al., 2016), ${ }^{207} \mathrm{~Pb} /{ }^{204} \mathrm{~Pb}=15.6258 \pm 0.0015 \quad(15.6239 \pm 0.0008 \quad 2 \mathrm{SD}$, Jweda et al., 2016) and ${ }^{208} \mathrm{~Pb} /{ }^{204} \mathrm{~Pb}=38.8346 \pm 0.0056$ 
(38.8287 \pm 0.0025 2SD, Jweda et al., 2016). Repeat analyses of AGV-1 $(\mathrm{n}=15)$ yielded ${ }^{206} \mathrm{~Pb} /{ }^{204} \mathrm{~Pb}=18.9037 \pm 0.0013$ (18.9054 \pm 0.0013 2SD, Weis et al., 2006), ${ }^{207} \mathrm{~Pb} /{ }^{204} \mathrm{~Pb}=15.6154 \pm 0.0009 \quad(15.6165 \pm 0.0001 \quad 2 \mathrm{SD}$, Weis et al., 2006) and ${ }^{208} \mathrm{~Pb} /{ }^{204} \mathrm{~Pb}=38.5755 \pm 0.0056$ (38.5875 $\pm 0.02202 \mathrm{SD}$, Weis et al., 2006). The reported literature values represent the acid-leached residues of BCR-2 and AGV-1 rock reference materials. The full procedural blanks for $\mathrm{Nd}, \mathrm{Pb}$ and $\mathrm{Sr}$ were below $40 \mathrm{pg}, 110 \mathrm{pg}$ and $2.5 \mathrm{ng}$, respectively. As such, the blank contamination contributed typically less than $1 \%$ to the individual sample yields with considerable effects only for the $\mathrm{Pb}$ isotopic composition of two samples (see Section 4.2.2).

\section{RESULTS}

\subsection{Lithogenic fluxes}

The lithogenic fluxes range from 0.24 to $20.47 \mathrm{~g} \mathrm{~m}^{-2}$ $\mathrm{yr}^{-1}$ (Fig. 2, Tab. 1). The samples located offshore New Zealand's South Island show the highest lithogenic fluxes in the study area $\left(0.72-20.47 \mathrm{~g} \mathrm{~m}^{-2} \mathrm{yr}^{-1}\right)$ but decrease with increasing distance to New Zealand (Fig. 2). The lithogenic fluxes in this area indicate a slight decline south of the Subtropical Front (STF) with highest values north of the STF (SO213_87-1, $20.47 \mathrm{~g} \mathrm{~m}^{-2} \mathrm{yr}^{-1}$ ) (Fig. 2). Locations close to the western Antarctic continental margin at approximately $70^{\circ} \mathrm{S}$ and $120^{\circ} \mathrm{W}$ to $90^{\circ} \mathrm{W}$ represent the area with the second-highest lithogenic fluxes ranging from 1.97 to $6.85 \mathrm{~g} \mathrm{~m}^{-2} \mathrm{yr}^{-1}$. East of $145^{\circ} \mathrm{W}$, lithogenic fluxes increase along two south-north transects $\left(\sim 120^{\circ} \mathrm{W}\right.$ and $\sim 90^{\circ} \mathrm{W}$ transect) spanning the winter sea ice limit (WSI), Antarctic Polar Front (APF) and Subantarctic Front (SAF). Both transects reveal highest values south of the WSI and a northward decrease in lithogenic fluxes (Fig. 2). However, the $\sim 90^{\circ} \mathrm{W}$ transect has slightly higher absolute lithogenic fluxes than the $\sim 120^{\circ} \mathrm{W}$ transect and shows a prominent decrease at the APF (Fig. 2). In contrast, lithogenic fluxes along the $\sim 120^{\circ} \mathrm{W}$ transect are characterized by a gradual decrease from the South to the North (Fig. 2). In the southeast Pacific north of the SAF, the lithogenic fluxes increase towards Patagonia $\left(0.96-2.80 \mathrm{~g} \mathrm{~m}^{-2}\right.$ $\left.\mathrm{yr}^{-1}\right)$. The samples located in the open ocean between $55^{\circ}$ $\mathrm{S}$ to $65^{\circ} \mathrm{S}$ and $180^{\circ} \mathrm{E}$ to $95^{\circ} \mathrm{W}$ show the lowest lithogenic fluxes among all samples $\left(0.38-1.06 \mathrm{~g} \mathrm{~m}^{-2} \mathrm{yr}^{-1}\right)$ (Fig. 2) (see Table 1).

Table 1

Lithogenic fluxes from the Pacific sector of the Sothern Ocean in $\mathrm{g} \mathrm{m}^{-2} \mathrm{yr}^{-1}$. WSP: Western South Pacific, CSP: Central South Pacific and ESP: Eastern South Pacific. For information about the sample locations and the calculation of the lithogenic fluxes see Table A4.

\begin{tabular}{|c|c|c|c|c|c|}
\hline \multicolumn{2}{|l|}{ WSP } & \multicolumn{2}{|l|}{ CSP } & \multicolumn{2}{|l|}{ ESP } \\
\hline Station & Lithogenic flux $\left(\mathrm{g} \mathrm{m}^{-2} \mathrm{yr}^{-1}\right)$ & Station & Lithogenic flux $\left(\mathrm{g} \mathrm{m}^{-2} \mathrm{yr}^{-1}\right)$ & Station & Lithogenic flux $\left(\mathrm{g} \mathrm{m}^{-2} \mathrm{yr}^{-1}\right)$ \\
\hline $70-1$ & 0.38 & $51-2$ & 0.95 & $34-1$ & 2.50 \\
\hline $72-3$ & 0.40 & $53-1$ & 1.22 & $45-1$ & 0.24 \\
\hline $74-1$ & 0.58 & $55-1$ & 0.49 & $46-1$ & 0.34 \\
\hline $76-1$ & 0.91 & $62-1$ & 0.65 & $49-1$ & 0.78 \\
\hline $80-2$ & 0.78 & $63-1$ & 0.59 & $280-1$ & 1.31 \\
\hline $82-2$ & 0.53 & $64-2$ & 1.06 & $290-1$ & 0.45 \\
\hline $84-1$ & 0.43 & $65-2$ & 1.92 & $291-3$ & 1.41 \\
\hline $85-2$ & 0.63 & $68-1$ & 1.82 & $292-1$ & 1.30 \\
\hline $91-6$ & 0.59 & $69-2$ & 1.46 & $2659-2$ & 1.72 \\
\hline $92-1$ & 0.62 & $213-54$ & 0.29 & $2661-4$ & 2.87 \\
\hline $94-3$ & 0.42 & $213-26$ & 0.29 & 2663-4 & 1.54 \\
\hline $95-6$ & 1.82 & $264-1$ & 3.18 & 26644 & 1.14 \\
\hline $97-5$ & 1.08 & $265-1$ & 2.64 & $2667-3$ & 1.46 \\
\hline $98-6$ & 2.31 & $266-4$ & 1.57 & $2684-1$ & 3.06 \\
\hline 99-1 & 0.72 & $267-4$ & 1.50 & $2687-5$ & 4.53 \\
\hline $100-1$ & 2.74 & $268-1$ & 2.15 & $2688-4$ & 5.12 \\
\hline $101-2$ & 2.95 & $269-4$ & 1.39 & $2690-1$ & 2.11 \\
\hline $104-2$ & 8.28 & $270-1$ & 1.33 & 2691-1 & 7.03 \\
\hline $105-1$ & 9.48 & $272-4$ & 1.09 & $2692-1$ & 2.90 \\
\hline 213-78 & 8.01 & 2744 & 1.08 & 2696-4 & 3.84 \\
\hline $213-76$ & 7.70 & $276-1$ & 0.49 & $2697-1$ & 5.38 \\
\hline $213-79$ & 3.41 & & & $2699-5$ & 1.84 \\
\hline $213-84$ & 11.84 & & & $2700-5$ & 2.14 \\
\hline \multirow[t]{9}{*}{$213-87$} & 20.47 & & & 2703-2 & 0.96 \\
\hline & & & & $2715-3$ & 1.50 \\
\hline & & & & $2716-2$ & 1.33 \\
\hline & & & & $213-22$ & 1.28 \\
\hline & & & & $251-1$ & 1.97 \\
\hline & & & & $252-1$ & 6.85 \\
\hline & & & & $253-1$ & 6.17 \\
\hline & & & & $255-1$ & 3.81 \\
\hline & & & & $258-1$ & 5.66 \\
\hline
\end{tabular}


Table 2

Rare earth element concentration of surface samples from the Pacific sector of the Southern Ocean. WSP: Western South Pacific, CSP: Central South Pacific and ESP: Eastern South Pacific. The ratios (subscript ' $\mathrm{N}$ ') and anomalies (asterisk) are normalized to the Upper Continental Crust (UCC) (Taylor and McLennan, 1995) and obtained from the following calculations: Eu/Eu* ${ }_{\mathrm{N}}=$ Eu $\underline{\left./\left(\mathrm{Sm}_{\mathrm{N}} \times \mathrm{Gd}_{\mathrm{N}}\right)^{0.5}, \mathrm{La}_{\mathrm{N}} / \mathrm{Yb}_{\mathrm{N}}, \mathrm{HREE} / \mathrm{LREE}_{\mathrm{N}}=\left(\mathrm{Tm}_{\mathrm{N}}+\mathrm{Yb}_{\mathrm{N}}+\mathrm{Lu}_{\mathrm{N}}\right) /\left(\mathrm{La}_{\mathrm{N}}+\mathrm{Pr}_{\mathrm{N}}+\mathrm{Nd}_{\mathrm{N}}\right) \text { and MREE} / \mathrm{MREE}_{\mathrm{N}}=\left(\mathrm{Gd}_{\mathrm{N}}+\mathrm{Tb}_{\mathrm{N}}+\mathrm{Dy}_{\mathrm{N}}\right) /\left[\left(\mathrm{Tm}_{\mathrm{N}}+\mathrm{Yb}_{\mathrm{N}}+\mathrm{Lu}_{\mathrm{N}}+\mathrm{La}_{\mathrm{N}}+\mathrm{Pr}_{\mathrm{N}}+\mathrm{Nd}_{\mathrm{N}}\right) / 2\right)\right] .}$

\begin{tabular}{|c|c|c|c|c|c|c|c|c|c|c|c|c|c|c|c|c|c|c|}
\hline Station & $\mathrm{La}$ & $\mathrm{Ce}$ & $\operatorname{Pr}$ & $\mathrm{Nd}$ & $\mathrm{Sm}$ & $\mathrm{Eu}$ & Gd & $\mathrm{Tb}$ & Dy & Ho & $\mathrm{Er}$ & $\mathrm{Tm}$ & $\mathrm{Yb}$ & $\mathrm{Lu}$ & $\mathrm{La}_{\mathrm{N}} / \mathrm{Yb}_{\mathrm{N}}$ & $\mathrm{Eu} / \mathrm{Eu}^{*}{ }_{\mathrm{N}}$ & $\mathrm{MREE} \mathrm{MREE}^{*}{ }_{\mathrm{N}}$ & ${\mathrm{HREE} / \mathrm{LREE}_{\mathrm{N}}}$ \\
\hline \multicolumn{19}{|l|}{$W S P$} \\
\hline $70-1$ & 0.59 & 1.76 & 0.13 & 0.46 & 0.11 & 0.03 & 0.11 & 0.02 & 0.09 & 0.02 & 0.06 & 0.01 & 0.08 & 0.01 & 0.53 & 1.41 & 0.99 & 1.86 \\
\hline $76-1$ & 10.49 & 25.96 & 2.39 & 8.93 & 1.87 & 0.70 & 1.69 & 0.23 & 1.58 & 0.31 & 0.98 & 0.15 & 1.04 & 0.15 & 0.74 & 1.85 & 1.05 & 1.35 \\
\hline $97-5$ & 5.67 & 17.58 & 1.37 & 5.13 & 1.06 & 0.31 & 1.13 & 0.16 & 0.98 & 0.20 & 0.59 & 0.09 & 0.62 & 0.09 & 0.67 & 1.31 & 1.17 & 1.46 \\
\hline $105-1$ & 25.16 & 52.23 & 6.24 & 24.09 & 5.05 & 1.16 & 4.61 & 0.70 & 4.10 & 0.82 & 2.33 & 0.34 & 2.35 & 0.34 & 0.79 & 1.13 & 1.19 & 1.20 \\
\hline \multicolumn{19}{|l|}{$C S P$} \\
\hline $51-2$ & 14.64 & 42.27 & 3.23 & 12.20 & 2.41 & 1.41 & 2.41 & 0.33 & 2.18 & 0.43 & 1.31 & 0.20 & 1.48 & 0.22 & 0.82 & 1.25 & 1.05 & 1.40 \\
\hline $62-1$ & 1.05 & 3.30 & 0.25 & 0.90 & 0.20 & 0.05 & 0.20 & 0.03 & 0.16 & 0.03 & 0.10 & 0.02 & 0.12 & 0.02 & 0.62 & 1.05 & 1.04 & 1.59 \\
\hline $64-2$ & 1.74 & 5.22 & 0.41 & 1.44 & 0.27 & 0.05 & 0.28 & 0.01 & 0.22 & 0.02 & 0.14 & 0.02 & 0.17 & 0.02 & 0.73 & 0.90 & 0.82 & 1.25 \\
\hline $266-4$ & 6.97 & 19.38 & 1.65 & 6.10 & 1.19 & 0.24 & 1.10 & 0.13 & 0.93 & 0.17 & 0.53 & 0.08 & 0.60 & 0.08 & 0.85 & 0.98 & 1.03 & 1.13 \\
\hline $268-1$ & 5.63 & 15.03 & 1.33 & 4.90 & 0.99 & 0.22 & 0.99 & 0.13 & 0.77 & 0.16 & 0.47 & 0.07 & 0.48 & 0.07 & 0.86 & 1.05 & 1.13 & 1.17 \\
\hline $272-4$ & 4.21 & 11.60 & 1.00 & 3.65 & 0.70 & 0.15 & 0.67 & 0.07 & 0.58 & 0.09 & 0.36 & 0.05 & 0.37 & 0.05 & 0.84 & 1.05 & 1.01 & 1.15 \\
\hline $276-1$ & 6.15 & 16.71 & 1.41 & 5.18 & 1.03 & 0.26 & 1.11 & 0.16 & 0.93 & 0.19 & 0.57 & 0.08 & 0.60 & 0.09 & 0.75 & 1.16 & 1.14 & 1.33 \\
\hline \multicolumn{19}{|l|}{$E S P$} \\
\hline $34-1$ & 17.85 & 48.18 & 4.23 & 16.27 & 3.38 & 0.82 & 3.16 & 0.47 & 2.98 & 0.60 & 1.84 & 0.27 & 1.94 & 0.28 & 0.67 & 1.18 & 1.10 & 1.43 \\
\hline $292-1$ & 17.85 & 48.18 & 4.23 & 16.27 & 3.38 & 0.82 & 3.16 & 0.47 & 2.98 & 0.60 & 1.84 & 0.27 & 1.94 & 0.28 & 0.67 & 1.18 & 1.10 & 1.43 \\
\hline $2687-5$ & 20.17 & 46.52 & 4.67 & 17.71 & 3.49 & 0.86 & 3.46 & 0.48 & 2.87 & 0.57 & 1.66 & 0.24 & 1.64 & 0.23 & 0.90 & 1.16 & 1.18 & 1.10 \\
\hline $2699-5$ & 13.94 & 34.40 & 3.30 & 12.66 & 2.56 & 0.64 & 2.52 & 0.38 & 2.25 & 0.46 & 1.37 & 0.20 & 1.38 & 0.20 & 0.74 & 1.18 & 1.16 & 1.31 \\
\hline $252-1$ & 27.11 & 63.42 & 6.25 & 23.78 & 4.63 & 1.00 & 4.08 & 0.59 & 3.63 & 0.71 & 2.11 & 0.31 & 2.11 & 0.30 & 0.94 & 1.09 & 1.09 & 1.06 \\
\hline $258-1$ & 24.18 & 57.36 & 5.69 & 21.42 & 4.20 & 0.96 & 4.20 & 0.58 & 3.38 & 0.67 & 1.93 & 0.28 & 1.93 & 0.28 & 0.92 & 1.08 & 1.19 & 1.07 \\
\hline
\end{tabular}




\subsection{Provenance sensitive proxies}

\subsubsection{Rare earth elements}

The REE concentration results $(n=17)$ are listed in Table 2. We normalized all REE concentration data to the Upper Continental Crust (UCC) (Taylor and McLennan, 1995) and thus present the data as UCC-normalized (subscript ' $N$ ') ratios and anomalies (asterisk) obtained from the following calculations: $\mathrm{Eu} / \mathrm{Eu}^{*}{ }_{\mathrm{N}}=\mathrm{Eu}_{\mathrm{N}} /\left(\mathrm{Sm}_{\mathrm{N}} \times\right.$ $\left.\mathrm{Gd}_{\mathrm{N}}\right)^{0.5}, \mathrm{La}_{\mathrm{N}} / \mathrm{Yb}_{\mathrm{N}}, \mathrm{HREE} / \mathrm{LREE}_{\mathrm{N}}=\left(\mathrm{Tm}_{\mathrm{N}}+\mathrm{Yb}_{\mathrm{N}}+\mathrm{Lu}_{\mathrm{N}}\right)$ / $\left(\mathrm{La}_{\mathrm{N}}+\mathrm{Pr}_{\mathrm{N}}+\mathrm{Nd}_{\mathrm{N}}\right)$ and MREE/MREE* ${ }_{\mathrm{N}}=\left(\mathrm{Gd}_{\mathrm{N}}+\right.$ $\left.\mathrm{Tb}_{\mathrm{N}}+\mathrm{Dy}_{\mathrm{N}}\right) /\left[\left(\mathrm{Tm}_{\mathrm{N}}+\mathrm{Yb}_{\mathrm{N}}+\mathrm{Lu}_{\mathrm{N}}+\mathrm{La}_{\mathrm{N}}+\mathrm{Pr}_{\mathrm{N}}+\mathrm{Nd}_{\mathrm{N}}\right)\right.$ / 2)]. $\mathrm{Eu} / \mathrm{Eu}^{*}{ }_{\mathrm{N}}$ values range from 0.90 to 1.85 and $\mathrm{La}_{\mathrm{N}} /$ $\mathrm{Yb}_{\mathrm{N}}$ ratios range from 0.53 to 0.94 (Fig. 3a). The majority of samples from the central South Pacific show the lowest $\mathrm{Eu} / \mathrm{Eu}^{*}{ }_{\mathrm{N}}$ ratios $(0.90-1.05)$ and intermediate $\mathrm{La}_{\mathrm{N}} / \mathrm{Yb}_{\mathrm{N}}$ ratios $(0.62-0.86)$. In contrast, the samples from the western part of the study area reveal the highest $\mathrm{Eu} / \mathrm{Eu}^{*}{ }_{\mathrm{N}}$ ratios (1.13-1.41) combined with the lowest $\mathrm{La}_{\mathrm{N}} / \mathrm{Yb}_{\mathrm{N}}$ ratios (0.53-0.79) (Fig. 3a, Tab. 2). The samples from the eastern part of the South Pacific can be characterized by intermediate $\mathrm{Eu} / \mathrm{Eu}^{*}{ }_{\mathrm{N}}(1.08-1.13)$ and $\mathrm{La}_{\mathrm{N}} / \mathrm{Yb}_{\mathrm{N}}$ ratios $(0.69-0.94)$ (Fig. 3a, Tab. 2). The HREE/LREE $\mathrm{N}_{\mathrm{N}}$ ratios show values from 1.06 to 1.86 and MREE/MREE* ${ }_{\mathrm{N}}$ ranges from 0.99 to 1.19 (Fig. 3b). The HREE/LREE N ratios and MREE/ MREE* ${ }_{N}$ ratios of samples from the Western, Central and Eastern South Pacific show no longitudinal and or latitudinal trends in the study area (Fig. 3b) (see Table 2).

\subsubsection{Lead isotopes}

The $\mathrm{Pb}$ isotope results $(\mathrm{n}=19)$ range from ${ }^{206} \mathrm{~Pb} /{ }^{204}$. $\mathrm{Pb}=18.40$ to $19.45,{ }^{207} \mathrm{~Pb} /{ }^{204} \mathrm{~Pb}=15.6297$ to 15.68 and ${ }^{208} \mathrm{~Pb} /{ }^{204} \mathrm{~Pb}=38.34$ to 39.50 (Fig. $4 \mathrm{a}$ and b, Tab. 3). The majority of our samples show intermediate ratios of 206. $\mathrm{Pb} /{ }^{204} \mathrm{~Pb}(18.75-18.97),{ }^{207} \mathrm{~Pb} /{ }^{204} \mathrm{~Pb}(15.65-15.66)$ and ${ }^{208}$. $\mathrm{Pb} /{ }^{204} \mathrm{~Pb}$ (38.67-38.93), comprising samples from across the entire study area. Four samples from the central and western part of the study area illustrate less radiogenic values $\left({ }^{206} \mathrm{~Pb} /{ }^{204} \mathrm{~Pb}=18.40\right.$ to $18.65,{ }^{207} \mathrm{~Pb} /{ }^{204} \mathrm{~Pb}=15.63$ $15.64,{ }^{208} \mathrm{~Pb} /{ }^{204} \mathrm{~Pb}=38.33-38.55$ ) (Fig. $4 \mathrm{a}$ and $\mathrm{b}$ ). The $\mathrm{Pb}$
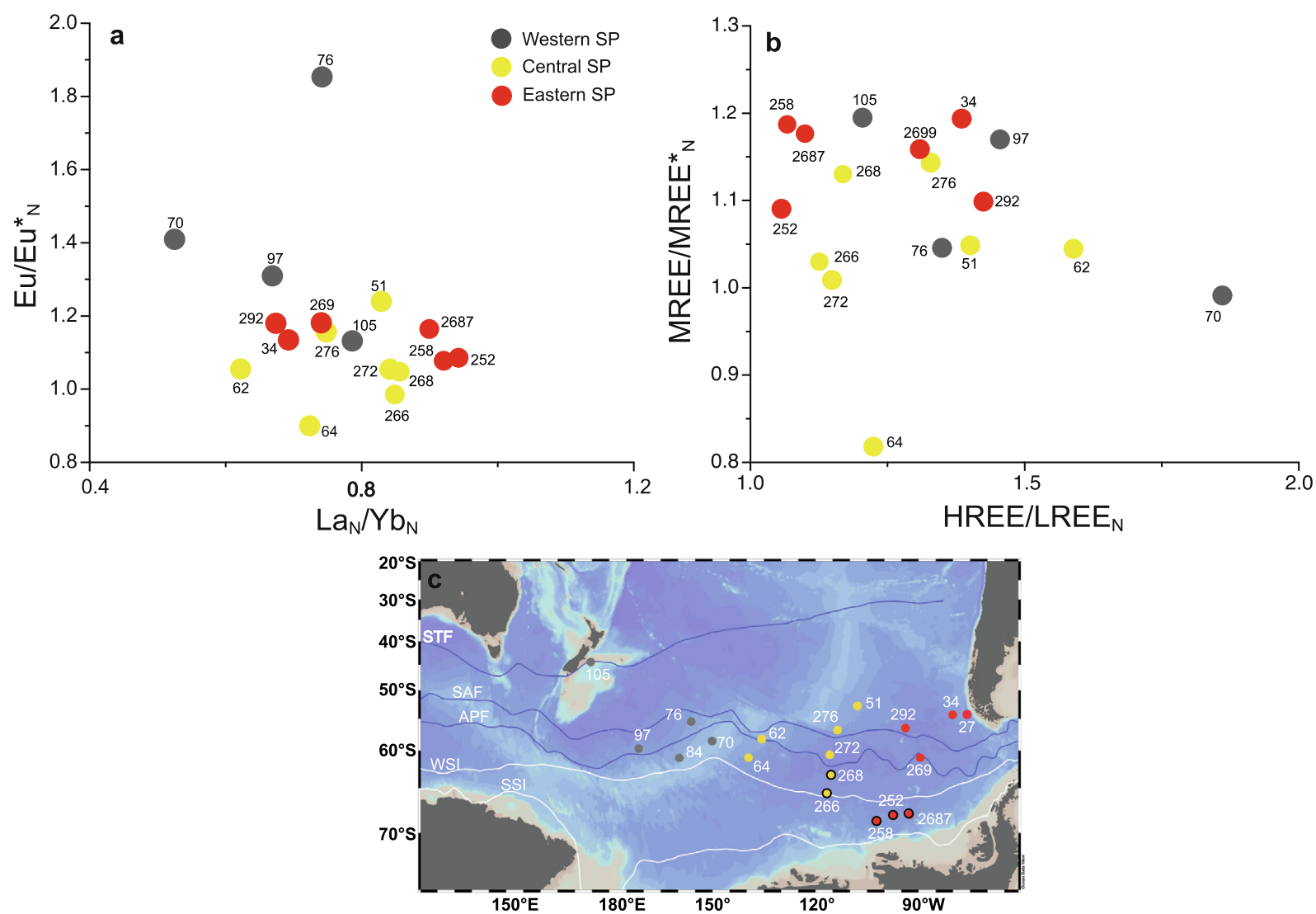

Fig. 3. a-c: Rare earth element composition of South Pacific dust samples and overview map of the samples used for provenance analysis. Rare earth element data are normalized to Upper Continental Crust (UCC) (Taylor and McLennan, 1995). Western SP (Western South Pacific), Central SP (Central South Pacific) and Eastern SP (Eastern South Pacific). The color code refers to the core locations shown in Fig. 3c. a: Eu-anomaly versus $\mathrm{La}_{\mathrm{N}} / \mathrm{Yb}_{\mathrm{N}}$. b: HREE/LREE ${ }_{\mathrm{N}}$ versus MREE/MREE* ${ }_{\mathrm{N}}$. c: Map of the South Pacific with locations of surface samples used for provenance analysis. White numbers are station numbers. Colored lines refer to mean positions of major frontal systems (Orsi et al., 1995). Samples with a black outline were not considered for the provenance analysis because they do not show a clear dust signal. STF: Subtropical Front, SAF: Subantarctic Front, APF: Antarctic Polar Front. Mean extension of winter and summer sea ice (WSI and SSI) is indicated by white lines. White dashed arrows show the direction of the Southern Westerly Winds. Symbols with black outline represent the samples that do not show a clear dust signal. The map was generated using the Ocean Data View software (Schlitzer, 2015). 
Table 3

$\mathrm{Sr}, \mathrm{Nd}$ and $\mathrm{Pb}$ isotopic compositions of surface samples from the Pacific sector of the Southern Ocean. WSP: Western South Pacific, CSP: Central South Pacific and ESP: Eastern South Pacific.

\begin{tabular}{|c|c|c|c|c|c|c|c|c|c|c|}
\hline Station & ${ }^{87} \mathrm{Sr} /{ }^{86} \mathrm{Sr}$ & $2 \mathrm{SD}$ & $\varepsilon \mathrm{Nd}$ & $2 \mathrm{SD}$ & ${ }^{206} \mathrm{~Pb} /{ }^{204} \mathrm{~Pb}$ & $2 \mathrm{SD}$ & ${ }^{208} \mathrm{~Pb} /{ }^{204} \mathrm{~Pb}$ & $2 \mathrm{SD}$ & ${ }^{207} \mathrm{~Pb} /{ }^{204} \mathrm{~Pb}$ & $2 \mathrm{SD}$ \\
\hline \multicolumn{11}{|l|}{$W S P$} \\
\hline $70-1$ & 0.710446 & 0.000035 & -4.3 & 0.34 & 18.5307 & 0.0015 & 38.4445 & 0.0056 & 15.6316 & 0.0015 \\
\hline $76-1$ & 0.709619 & 0.000035 & -4.4 & 0.34 & 18.9010 & 0.0015 & 38.8663 & 0.0056 & 15.6555 & 0.0015 \\
\hline $84-1$ & 0.710855 & 0.000035 & -6.0 & 0.34 & 18.4059 & 0.0015 & 38.3561 & 0.0056 & 15.6310 & 0.0015 \\
\hline $97-5$ & 0.709106 & 0.000035 & -3.8 & 0.34 & 18.9053 & 0.0015 & 38.9381 & 0.0056 & 15.6565 & 0.0015 \\
\hline $105-1$ & 0.709713 & 0.000035 & -4.2 & 0.34 & 19.4451 & 0.0015 & 39.5014 & 0.0056 & 15.6797 & 0.0015 \\
\hline \multicolumn{11}{|l|}{$C S P$} \\
\hline $51-2$ & 0.710137 & 0.000035 & -4.2 & 0.34 & 18.8178 & 0.0015 & 38.7798 & 0.0056 & 15.6449 & 0.0015 \\
\hline $62-1$ & 0.710498 & 0.000035 & -4.8 & 0.34 & 18.3986 & 0.0015 & 38.3358 & 0.0056 & 15.6272 & 0.0015 \\
\hline $64-2$ & 0.711733 & 0.000035 & -4.8 & 0.34 & 18.6523 & 0.0015 & 38.5508 & 0.0056 & 15.6391 & 0.0015 \\
\hline $266-4$ & 0.709895 & 0.000035 & -4.5 & 0.34 & 18.8825 & 0.0015 & 38.7908 & 0.0056 & 15.6498 & 0.0015 \\
\hline $268-1$ & 0.709756 & 0.000035 & -4.6 & 0.34 & 18.8617 & 0.0015 & 38.7678 & 0.0056 & 15.6464 & 0.0015 \\
\hline $272-4$ & 0.710190 & 0.000035 & -4.7 & 0.34 & 18.7440 & 0.0015 & 38.6691 & 0.0056 & 15.6429 & 0.0015 \\
\hline $276-1$ & 0.709731 & 0.000035 & -4.4 & 0.34 & 18.9698 & 0.0015 & 38.9291 & 0.0056 & 15.6565 & 0.0015 \\
\hline \multicolumn{11}{|l|}{$E S P$} \\
\hline $34-1$ & 0.708625 & 0.000035 & -4.2 & 0.34 & 18.8721 & 0.0015 & 38.8272 & 0.0056 & 15.6415 & 0.0015 \\
\hline $292-1$ & 0.708761 & 0.000035 & -3.0 & 0.34 & 18.8700 & 0.0015 & 38.7850 & 0.0056 & 15.6461 & 0.0015 \\
\hline $2687-5$ & 0.708950 & 0.000035 & -4.4 & 0.34 & 18.8866 & 0.0015 & 38.7886 & 0.0056 & 15.6489 & 0.0015 \\
\hline $2699-5$ & 0.708588 & 0.000035 & -3.2 & 0.34 & 18.8455 & 0.0015 & 38.7309 & 0.0056 & 15.6468 & 0.0015 \\
\hline $252-1$ & 0.709593 & 0.000035 & -5.0 & 0.34 & 18.8679 & 0.0015 & 38.7696 & 0.0056 & 15.6486 & 0.0015 \\
\hline $258-1$ & 0.709091 & 0.000035 & -4.2 & 0.34 & 18.8883 & 0.0015 & 38.7674 & 0.0056 & 15.6498 & 0.0015 \\
\hline $027-1$ & 0.709442 & 0.000027 & -4.8 & 0.26 & 18.9416 & 0.0015 & 38.9284 & 0.0056 & 15.6461 & 0.0015 \\
\hline
\end{tabular}

blanks of the samples PS75/70-1 and 84-1 exceed the critical value of $1 \%(70-1=4 \%, 84-1=2.7 \%)$ which could have caused a deviation from their real $\mathrm{Pb}$ isotope ratios. Therefore, we applied a blank correction assuming the worst case contamination scenario using the lowest sample $\mathrm{Pb}$ content ( $3 \mathrm{ng})$, the respective batch $\mathrm{Pb}$ blank $(110 \mathrm{pg}$ ) and the measured laboratory $\mathrm{Pb}$ isotope signature. These calculations reveal that blank contamination had a relevant effect on only two samples (PS75/70-1 and 84-1). We added the blank-corrected values for these samples to our supplementary data file (Tab. A 1). Sample PS75/105-1 located off New Zealand shows unusual $\mathrm{Pb}$ isotopic compositions $\left({ }^{208}\right.$ $\mathrm{Pb} /{ }^{204} \mathrm{~Pb}=39.50$ and $\left.{ }^{206} \mathrm{~Pb} /{ }^{204} \mathrm{~Pb}=19.45\right)$, inconsistent with the REE and Sr-Nd isotope data from the same sample and potential local background and with cross contamination. However, we cannot reconcile this offset with the available data, and therefore exclude the $\mathrm{Pb}$ results of PS75/105-1 from the discussion.

\subsubsection{Strontium and neodymium isotopes}

The $\mathrm{Sr}$ isotope results $(\mathrm{n}=19$, Tab. 3) range from ${ }^{87} \mathrm{Sr} /{ }^{86} \mathrm{Sr}=0.7086$ to 0.7117 and $\varepsilon \mathrm{Nd}(\mathrm{n}=19)$ reveals values from -3.0 to -6.0 (Fig. 4 c). In $\mathrm{Nd}-\mathrm{Sr}$ space, surface samples from the Western and Central South Pacific range from ${ }^{87} \mathrm{Sr} /{ }^{86} \mathrm{Sr}=0.7091$ to 0.7109 and $\varepsilon \mathrm{Nd}=-3.8$ to -4.4 and ${ }^{87} \mathrm{Sr} /{ }^{86} \mathrm{Sr}=0.7098$ to 0.7117 and $\varepsilon N d=-4.2$ to -4.8 , respectively (Fig. 4 c). In contrast, the samples from the eastern South Pacific reveal the least radiogenic ${ }^{87} \mathrm{Sr} /{ }^{86} \mathrm{Sr}$ ratios from 0.7086 to 0.7091 combined with the most radiogenic $\varepsilon N d$ values of -3.0 to -4.2 (Fig. 4 c).

\section{DISCUSSION}

\subsection{Lithogenic fluxes}

Only a few studies (e.g. Chase et al., 2003; Bradtmiller et al., 2009) have published lithogenic flux data for the Pacific sector of the Southern Ocean. Consequently, most dust deposition estimates for this area are based on climate/dust models (e.g. Mahowald et al., 2006; Maher et al., 2010; Albani et al., 2012; Albani et al., 2014). While our modern lithogenic fluxes are consistent with the data provided by Chase et al. (2003) and Bradtmiller et al. (2009) the modern modeled deposition in the Southern Ocean underestimates the sediment-derived lithogenic fluxes by up to a factor of $\sim 10$ (e.g. Albani et al., 2014) (Fig. 2).

The highest lithogenic fluxes offshore New Zealand's South Island might reflect a combination of Australian/ New Zealand sourced dust input admixed with riverine input from New Zealand sources (Fig. 2). Terrigenous tracers including plant wax n-alkanes and soil derived branched glycerol dialkyl glycerol tetraethers (Jaeschke et al., 2017) provide independent evidence for increased terrigenous input at our sample locations (Fig. A 1). South of New Zealand $\left(50^{\circ} \mathrm{S}\right.$ and $\left.164^{\circ} \mathrm{E}\right)$ lithogenic fluxes increase to $8.30 \mathrm{~g} \mathrm{~m}^{-2} \mathrm{yr}^{-1}$ (Fig. 2) (Bradtmiller et al., 2009). Because New Zealand sourced input can be excluded at this location the lithogenic fluxes are probably related to Australian dust. In the open ocean $\left(55^{\circ} \mathrm{S}\right.$ to $65^{\circ} \mathrm{S}$ and $180^{\circ} \mathrm{E}$ to $95^{\circ}$ $\mathrm{W})$, we observe the lowest lithogenic fluxes (0.38 $1.06 \mathrm{~g} \mathrm{~m}^{-2} \mathrm{yr}^{-1}$ ) (Fig. 2), which are consistent with the low- 

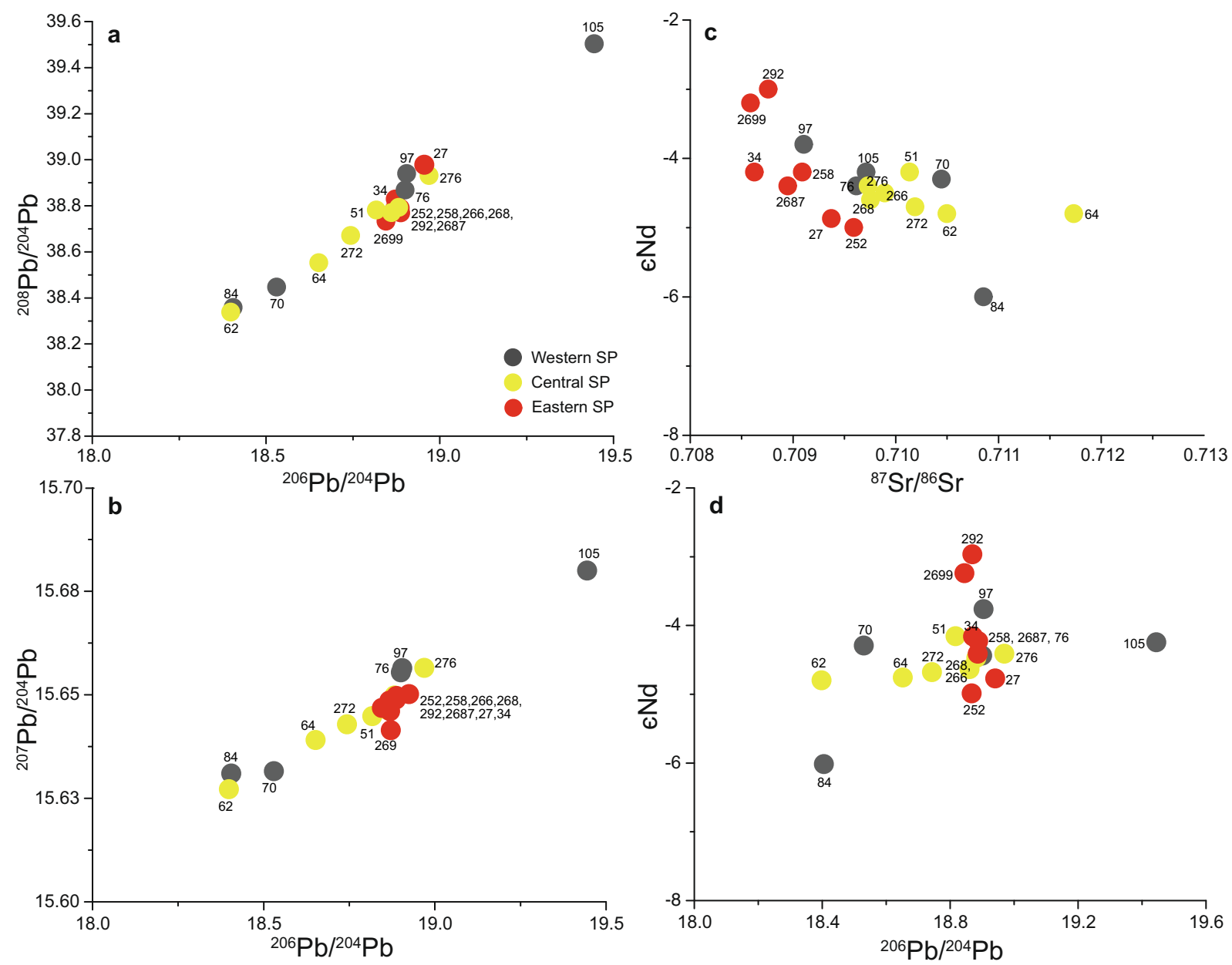

Fig. 4. a-d: Isotopic composition of South Pacific dust samples. Western SP (Western South Pacific), Central SP (Central South Pacific) and Eastern SP (Eastern South Pacific). a-b: Lead isotope results are presented as ${ }^{206} \mathrm{~Pb} /{ }^{204} \mathrm{~Pb}$ versus ${ }^{208} \mathrm{~Pb} /{ }^{204} \mathrm{~Pb}$ and ${ }^{206} \mathrm{~Pb} /{ }^{204} \mathrm{~Pb}$ versus ${ }^{207} \mathrm{~Pb} / 204 \mathrm{~Pb}$. c: $\varepsilon \mathrm{Nd}$ versus ${ }^{87} \mathrm{Sr} /{ }^{86} \mathrm{Sr}$ ratios. d: $\varepsilon \mathrm{Nd}$ versus ${ }^{206} \mathrm{~Pb} /{ }^{204} \mathrm{~Pb}$ ratios. Error bars for $\varepsilon_{\mathrm{Nd}},{ }^{87} \mathrm{Sr} /{ }^{86} \mathrm{Sr},{ }^{208} \mathrm{~Pb} /{ }^{204} \mathrm{~Pb},{ }^{206} \mathrm{~Pb} /{ }^{204} \mathrm{~Pb} \mathrm{and}$ ${ }^{207} \mathrm{~Pb} /{ }^{204} \mathrm{~Pb}$ ratios are smaller than the symbols. The color code of the South Pacific dust samples refers to the core locations shown Fig. $3 \mathrm{c}$. (For interpretation of the references to colour in this figure legend, the reader is referred to the web version of this article.)

est fluxes of leaf wax n-alkanes (Jaeschke et al., 2017) (Fig. A 1). Leaf wax n-alkanes are major components of higher land plants, preserved in soil they can be transported to the marine realm by erosion, wind, riverine input and smoke aerosols (Eglinton and Hamilton, 1967; Eglinton and Eglinton, 2008). Subsequently, the occurrence of leaf wax n-alkanes in marine sediments is indicative for lithogenic input from land masses with higher land plants. The absence of higher land plants on Antarctica therefore rules out an Antarctic contribution to the n-alkanes in our samples. Moreover, based on the large distance of the open ocean samples from potential source areas (PSAs), we exclude the input of fluvial derived sediment advected to our open ocean sample locations. In addition, through normalizing ${ }^{232} \mathrm{Th}$ (common $\mathrm{Th}$ ) concentrations to the flux of ${ }^{230} \mathrm{Th}_{\mathrm{xs}}$, we calculated lithogenic fluxes which are unaffected by lateral sediment redistribution at the seafloor. The correction for lateral sediment redistribution relies on the assumption that the lateral distributed and the vertically deposited sediment have identical Th concentrations, so that the flux calculation is not biased through lateral input (Geibert et al., 2005). In the remote open ocean, the ${ }^{232} \mathrm{Th}$ isotope can be used as a dust proxy because particles derived from continents are the only known source of ${ }^{232} \mathrm{Th}$ to the ocean (Brewer et al., 1980). Hence, we suggest that the open ocean lithogenic fluxes are solely derived from atmospheric dust input. Lithogenic fluxes north of the SAF $\left(51^{\circ} \mathrm{S}\right.$ to $57^{\circ} \mathrm{S}$ and $95^{\circ} \mathrm{W}$ to $\left.80^{\circ} \mathrm{W}\right)$ range from 0.96 to $2.80 \mathrm{~g} \mathrm{~m}^{-2} \mathrm{yr}^{-1}$ with increasing lithogenic fluxes towards Patagonia, likely indicating a slightly elevated eolian deposition signal (Fig. 2). Tournadre et al. (2012) suggest that some icebergs travel further north than the iceberg maximum concentration at approximately $150^{\circ} \mathrm{W}$ (Fig. 2), where the ACC transports these icebergs eastward (Tournadre et al., 2012). Therefore, we assume that the high lithogenic fluxes along the $\sim 120^{\circ} \mathrm{W}$ transect south of the APF represent the influence of ice-rafted sediment resulting in increased lithogenic fluxes. This is supported by the occur- 
rence of gravel particles in surface sediments in a nearby north to south transect located in the central Amundsen Sea (Hillenbrand, 2000). North of the APF, the lithogenic fluxes decrease markedly, suggesting dust as the main lithogenic source (Fig. 2). The high lithogenic fluxes south of the WSI in the $\sim 90^{\circ} \mathrm{W}$ transect cannot be solely explained by ice-rafted sediment input, because of an eastward decrease in iceberg probability (Fig. 2) (Tournadre et al., 2012). In addition, the southernmost location of these samples rules out dust input from Australian/New Zealand PSAs. Rather we argue that this increase reflects the presence of Antarctic Peninsula-derived turbidity currents (Rebesco et al., 1996; Hillenbrand, 2000; Esper et al., 2010) resulting in elevated lithogenic fluxes (Fig. 2). The occurrence of turbidity currents in this area was shown by the presence of moundshaped sedimentary bodies between $63^{\circ} \mathrm{S}$ and $69^{\circ} \mathrm{S}$, which consist of fine-grained sediment material derived from turbidity currents (Rebesco et al., 1996). In addition, Esper et al. (2010) studied the diatom distribution and preservation in southeastern Pacific surface sediments using the same sample transects $\left(90^{\circ} \mathrm{W}\right.$ and $\left.120^{\circ} \mathrm{W}\right)$. The best diatom preservation rates were found in the $120^{\circ} \mathrm{W}$ transect, whereas the samples in the $90^{\circ} \mathrm{W}$ transect show only midranging diatom concentrations and moderate diatom preservation rates. The differences in diatom occurrence and preservation rates in the two transects were explained by increased sediment input through turbidity currents from the Antarctic Peninsula affecting the preservation of biogenic opal after the deposition (Esper et al., 2010).

\subsection{Extraction of the dust signal from marine sediments}

This is the first targeted investigation of dust provenance using surface sediments from the Pacific sector of the Southern Ocean. To identify the most reliable and robust procedure for the extraction of the original dust signal from our marine sediment samples, we tested different leaching protocols and analyzed subsamples of leached sediment residues for their REE content, $\mathrm{Nd}, \mathrm{Sr}$ and $\mathrm{Pb}$ isotopic composition (Section 3.3). We considered this approach to be necessary because the preparation of our samples required different sedimentological methods (e.g. wet sieving and grain size separation) to receive the dust fraction (Section 3.3). The different methods applied to the samples may have had the potential to contaminate the samples with metal-bearing phases introduced during the sample preparation and grain size separation.

The REE data show no significant differences between the different leaching approaches, whereas small differences are evident for $\mathrm{Nd}$ and $\mathrm{Sr}$ isotopes (Tab. A2). Yet, the most sensitive tracer among the geochemical tools used in this study are $\mathrm{Pb}$ isotopes which indeed resolve significant differences between the leaching approaches. Repeated HH$\mathrm{AcOH}$ leaching removed a fraction which carried an unradiogenic $\mathrm{Pb}$ isotope signature (Fig. 5, Tab. A2). Typical sources of an unradiogenic $\mathrm{Pb}$ isotopic composition in the detrital residue of acid-leached marine sediments can comprise incomplete removal of authigenic seawater-derived precipitates (Frank, 2002) and/or contamination from local (anthropogenic) background particles (Bollhöfer and

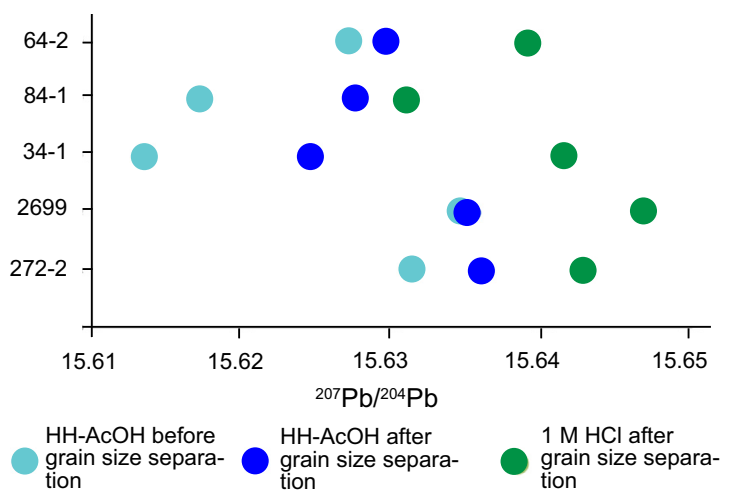

Fig. 5. Results of the leaching experiment for ${ }^{207} \mathrm{~Pb} /{ }^{204} \mathrm{~Pb}$. The $y$-axis shows the five selected samples that were used for the comparison. The samples can be tracked in Fig. 1.

Rosman, 2001) e.g. introduced during sample preparation. The exposure to the $\mathrm{HCl}$-based leaching protocol removed additional fractions of unradiogenic $\mathrm{Pb}$ isotopic composition from the sample matrix (Fig. 5) suggesting that the $\mathrm{HCl}$-based leaching was more efficient in removing the contaminant phases from our sediment samples.

It is noted that clay minerals may be subject to partial dissolution when exposed to strong acids. However, Carroll and Starky (1971) showed that many abundant clay minerals remain largely intact after exposure to $6.45 \mathrm{M} \mathrm{HCl}$ over 10 days. Hence, we are confident that the benefits of complete removal of authigenic and/or contaminant phases by our HCl-based leaching protocol outweigh potential partial dissolution of clay minerals. In addition, the use of our HCl-based leaching protocol allows better comparison with recent results from important terrestrial dust source areas which applied $\mathrm{HCl}$-based leaching protocols to extract original silicate fine fraction signals from sediments (Gili et al., 2017). A further benefit is the rigorous external quality control provided by processing our rock reference materials and samples with the same leaching protocol.

\subsubsection{Geochemical fingerprinting of South Pacific dust}

We compare our dust fraction $(<10 \mu \mathrm{m})$ to PSA data from southern South America, New Zealand and Australia. For the interpretation of PSAs to the South Pacific we exclusively use the open ocean samples with the lowest lithogenic fluxes (see Section 5.1). It should be noted that the southern South American PSA data have been measured on the $<5 \mu \mathrm{m}$ fraction (Delmonte et al., 2004; Sugden et al., 2009; Gili et al., 2016; Gili et al., 2017). The REE data from Australia include the coarse fraction $(<90 \mu \mathrm{m})$, whereas REE data from New Zealand have been measured on material from dust traps, glacier and loess deposits (Marx et al., 2005; McGowan et al., 2005; Marx and Kamber, 2010; this work). The Australian and New Zealand $\mathrm{Sr}, \mathrm{Nd}$ and $\mathrm{Pb}$ PSA data were obtained from the fine fraction $(<2 \mu \mathrm{m}$ and $<5 \mu \mathrm{m})$ (Delmonte et al., 2004; Gingele and De Deckker, 2005; Revel-Rolland et al., 2006; De Deckker et al., 2010; Vallelonga et al., 2010). While it has been shown that $\mathrm{Nd}$ and $\mathrm{Pb}$ isotopes show only 
little grain size dependency (Goldstein et al., 1984; Meyer et al., 2011; Gili et al., 2016; Gili et al., 2017), Sr isotopes tend towards substantially higher isotopic ratios in the fine fraction (Dasch, 1969; Blum et al., 1993; Blum and Erel, 1997). Our parallel analysis of the $<5 \mu \mathrm{m}$ and $<10 \mu \mathrm{m}$ fraction, however, shows no or only a very small grain size dependency for $\mathrm{Nd}$ isotopes (Fig. 6a, Tab. A 3) and a very small grain size dependency for $\mathrm{Sr}$ isotopes (Fig. 6 b, Tab. A 3). We did not evaluate potential grain size effects on REE. However, studies show contradicting results ranging from no significant grain size dependency to large variations within different grain size fractions (Honda et al., 2004; Kanayama et al., 2005; Feng et al., 2011; Gili et al., 2017).

\subsubsection{Is there a southern South American component in the} South Pacific dust?

Many studies strongly emphasize the role of dust derived from southern South America in locations as remote as Antarctica, especially during past glacial periods, thereby indicating its long-range transport potential (e.g. Delmonte et al., 2004; Vallelonga et al., 2010; Gili et al., 2016; Delmonte et al., 2017; Gili et al., 2017). Source areas located on the western side of the Andes in northern South America primarily supply dust to the eastern Equatorial Pacific and show different isotopic compositions in $\mathrm{Pb}$ isotope space compared to our South Pacific dust samples (Pichat et al., 2014) (Fig. 8a and b). Hence, westward dust transport from southern South American dust sources to our study area can be excluded. Given the direction of the SWW, eastward circumpolar dust transport appears to be the only mechanism to supply dust from southern South American sources to the Pacific sector of the Southern Ocean. However, modern air mass (Neff and Bertler, 2015) and dust (Tanaka and Chiba, 2006; Li et al., 2008) modeling studies in the Southern Hemisphere clearly show that wind trajectories and dust plumes originating on the eastern side of the Andes and Patagonia are predominantly transported eastward to the Atlantic sector of the Southern Ocean and do not reach our study area. Besides the physical constraints of dust input to the Pacific sector of the Southern Ocean, we emphasize that the REE data also do not support input from northern South American and Patago- nian sources. Given the geographical distance from these sources to the Pacific sector of the Southern Ocean and that the PSAs were exclusively located at eastern side of the Andes or in eastern Patagonia, we suggest that a potential influence of these sources would be highest in the western part of our study area. However, especially our samples from the western South Pacific do not correspond with the South American source areas (Fig. 7a and b). In addition, our isotopic data are clearly confined in $\mathrm{Nd}-\mathrm{Sr}$ and in $\mathrm{Pb}$ space (Fig. 8a-d). We argue that zonally varying contributions of South American dust to the Pacific sector of the Southern Ocean would result in a less confined isotopic pattern.

\subsubsection{New Zealand and Australian potential dust source areas}

The calculated South Pacific Eu/Eu* ${ }_{N}$ versus $\mathrm{La}_{\mathrm{N}} / \mathrm{Yb}_{\mathrm{N}}$ and HREE/LREE ${ }_{\mathrm{N}}$ versus MREE/MREE* ${ }_{\mathrm{N}}$ enable us to effectively rule out New Zealand as a PSA to the South Pacific because of considerably different REE anomalies and ratios compared to our samples (Fig. $7 \mathrm{a}$ and $\mathrm{b}$ ). Therefore, the distinct disagreement between our South Pacific dust samples and New Zealand dust sources in REE space clearly illustrates that New Zealand is not a significant source of dust to the South Pacific during the Holocene (Fig. 7a and b).

Australian PSAs include data from the Lake Eyre Basin and the Murray-Darling Basin as the most active dust sources in Australia today (Fig. 8e). Our South Pacific $\mathrm{Eu} / \mathrm{Eu}^{*}{ }_{\mathrm{N}}$ versus $\mathrm{La}_{\mathrm{N}} / \mathrm{Yb}_{\mathrm{N}}$ and $\mathrm{HREE} / \mathrm{LREE}_{\mathrm{N}}$ versus MREE/MREE* ${ }_{N}$ ratios are broadly encircled by $\mathrm{REE}$ ratios representative of the Darling area and the Murray area (Fig. 7a and b). The REE ratios from the Lake Eyre Basin also correspond with our South Pacific dust samples (Fig. 7a and b). However, based on the REE anomalies and ratios it appears to be difficult to identify potential Australian source areas to the South Pacific.

In $\mathrm{Pb}$ space, our South Pacific ${ }^{206} \mathrm{~Pb} /{ }^{204} \mathrm{~Pb}$ and ${ }^{208}$. $\mathrm{Pb} /{ }^{204} \mathrm{~Pb}$ ratios clearly correspond with ${ }^{206} \mathrm{~Pb} /{ }^{204} \mathrm{~Pb}$ and ${ }^{208}$. $\mathrm{Pb} /{ }^{204} \mathrm{~Pb}$ ratios from the Lake Eyre Basin (Fig. 9a). In contrast, ${ }^{206} \mathrm{~Pb} /{ }^{204} \mathrm{~Pb}$ and ${ }^{208} \mathrm{~Pb} /{ }^{204} \mathrm{~Pb}$ ratios from the Murray-Darling Basin are mainly less radiogenic. Only the most radiogenic samples from this area match the data
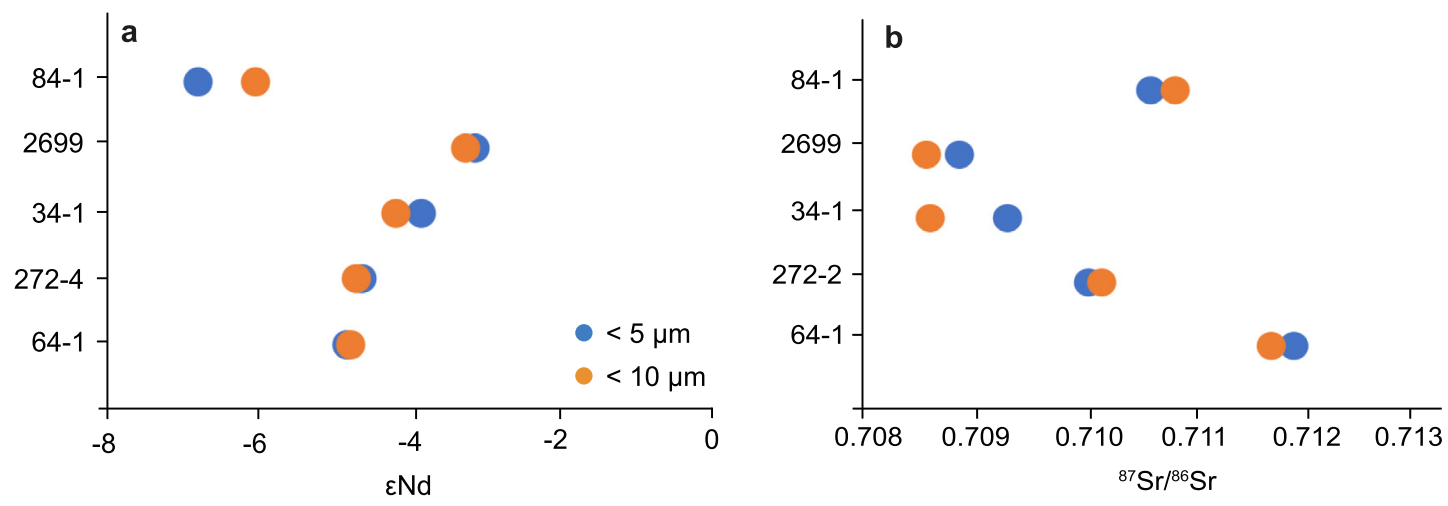

Fig. 6. a and b: a: Grain size comparison for $\varepsilon N d$. b: Grain size comparison for ${ }^{87} \mathrm{Sr} /{ }^{86} \mathrm{Sr}$. The y-axis shows the five selected samples that were used for the comparison. The samples can be tracked in Fig. 1. 

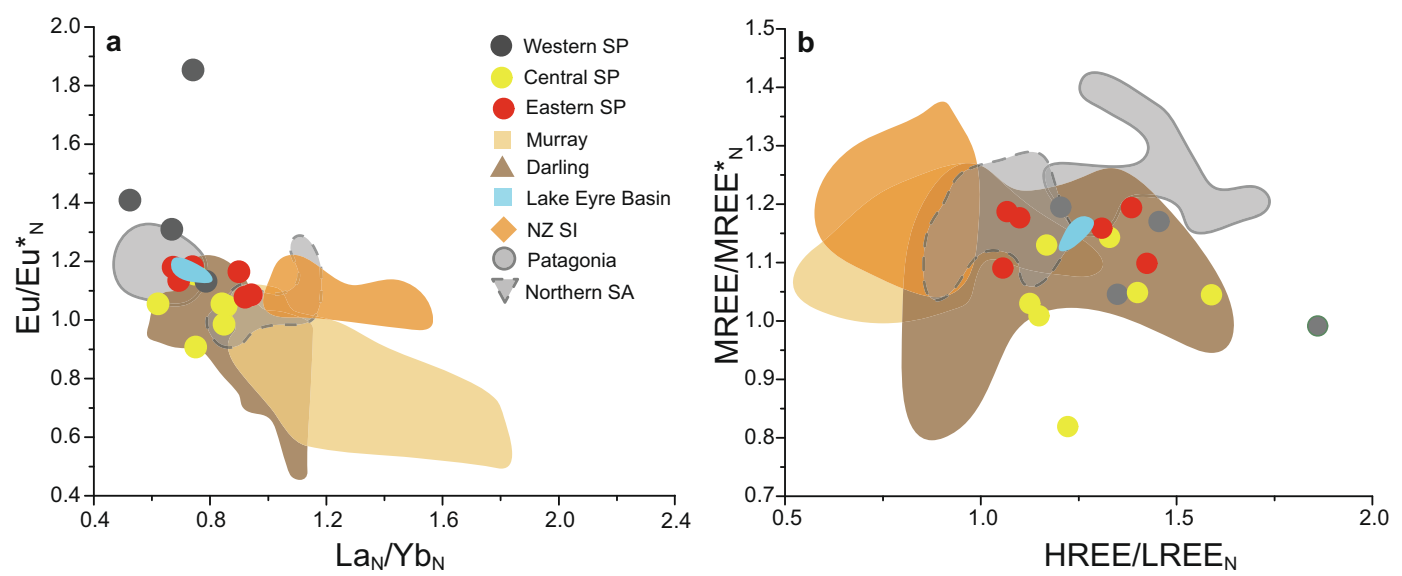

Fig. 7. a and b: Rare earth element composition of samples located in northern South American (Northern SA), Patagonian, Australian (Lake Eyre Basin and Murray-Darling Basin) and New Zealand South Island (NZ SI) source areas versus dust samples from the western, central and eastern South Pacific. Rare earth element data are normalized to Upper Continental Crust (UCC) (Taylor and McLennan, 1995). Western SP (Western South Pacific), Central SP (Central South Pacific) and Eastern SP (Eastern South Pacific). a: Eu-anomaly versus La $/$ $\mathrm{Yb}_{\mathrm{N}}$. b: HREE/LREE $\mathrm{N}_{\mathrm{N}}$ versus MREE/MREE*. Northern South America and Patagonia $(<5 \mu \mathrm{m})$ (Gili et al., 2016). Murray-Darling Basin $(<90 \mu \mathrm{m})$ (Marx and Kamber, 2010), Lake Eyre Basin $(<80 \mu \mathrm{m})$ (McGowan et al., 2005). New Zealand South Island (dust traps, glacier and loess deposits) (Marx et al., 2005). The color code of the South Pacific dust samples refers to the core locations shown Fig. 3c. The color and symbol code of the source areas refers to Fig. 8e-f. (For interpretation of the references to colour in this figure legend, the reader is referred to the web version of this article.)

of our samples from the South Pacific (Fig. 9a). The ${ }^{207}$ $\mathrm{Pb} /{ }^{204} \mathrm{~Pb}$ and ${ }^{206} \mathrm{~Pb} /{ }^{204} \mathrm{~Pb}$ data from the Murray-Darling Basin are clearly less radiogenic and overlap only with four samples from the South Pacific (Fig. 9b). The ${ }^{207} \mathrm{~Pb} /{ }^{204} \mathrm{~Pb}$ and ${ }^{206} \mathrm{~Pb} /{ }^{204} \mathrm{~Pb}$ ratios from the Lake Eyre Basin reveal a slight offset compared to our samples (Fig. 9b). However, it was shown that potential anthropogenic $\mathrm{Pb}$ contamination may affect the Australian PSA Pb isotopic composition and thus, may limit the use of $\mathrm{Pb}$ isotopes in provenance studies (e.g. Kamber et al., 2010). Therefore, it was recommended that the identification of PSAs should not rely on $\mathrm{Pb}$ isotopes alone (e.g. Kamber et al., 2010).

In Nd-Sr space, our South Pacific dust samples clearly correspond with samples from the Lake Eyre Basin (Fig. 9c). The majority of the Darling area samples are more radiogenic in $\varepsilon N d$, whereas the ${ }^{87} \mathrm{Sr} /{ }^{86} \mathrm{Sr}$ ratios are similar to those of our South Pacific dust samples (Fig. 9c). The $\mathrm{Nd}$ and $\mathrm{Sr}$ isotope data from the Murray area show different $\mathrm{Sr}-\mathrm{Nd}$ isotopic compositions compared to our South Pacific dust samples (Fig. 9c). In Nd-Pb space, the samples from the Lake Eyre Basin and the Darling area partly correspond with our samples from the South Pacific. In contrast, the Murray area shows a different orientation in $\mathrm{Nd}-\mathrm{Pb}$ space (Fig. 9d). Calculated mixing trends between the potential Australian source areas in Nd-Sr and $\mathrm{Nd}-\mathrm{Pb}$ isotope space reveal that mixing between the Darling and Murray areas can be ruled out for all but two samples (Fig. 9d). In contrast, a mixture of the Lake Eyre Basin and the Darling area is the most likely source of dust to the South Pacific during the Holocene (Fig. 9c and d). If at all, Murray sources contribute only small amounts to the South Pacific dust fraction (Fig. 9c and d).

Consequently, based on the consistency between the Lake Eyre Basin PSA data and our South Pacific dust samples, we suggest that the Lake Eyre Basin is the dominant source of dust to the South Pacific in the Holocene. However, we emphasize that the Darling area also provides a minor source of dust. Our provenance results are consistent with model-based investigations of modern dust distribution in the Southern Hemisphere, which suggest that dust from the Australian continent has the potential to dominate dust accumulation across the whole Pacific sector of the Southern Ocean (Li et al., 2008). Satellite observations identified the Lake Eyre Basin to be the most active source of dust in Australia (Prospero et al. 2002; Ginoux et al., 2012) and modeled modern dust transport pathways originating in the Lake Eyre Basin show that dust transported via the southeast dust transport corridor and the prevailing SWW can supply dust to large parts of the South Pacific, even as far as southern South America (McGowan and Clark, 2008). Based on two samples (PS75/034-1 and PS97/027-1) close to Patagonia and their isotopic composition identical to the remaining samples, we are able to support the long-range transport potential of Lake Eyre Basin derived dust (Figs. 3c, 4a-d).

\subsubsection{The role of airborne mineral dust for the supply of iron to the South Pacific}

Based on our lithogenic flux data set, we are able to distinguish between different sediment transport mechanisms to the Southern Ocean. However, we emphasize that the open ocean samples show dust-derived lithogenic fluxes (see Section 5.1). In this context, the process of natural iron fertilization needs to be considered, which is an effective way drawing down atmospheric $\mathrm{CO}_{2}$ by stimulating the biological productivity through the input of iron (Fe) to the ocean (Martin, 1990). Based on distinct similarities of Antarctic $\mathrm{CO}_{2}$, temperature and dust records (Jouzel et al., 2007; Lambert et al., 2008; Lüthi et al., 2008; Lambert et al., 2012) with Fe records from the Pacific 

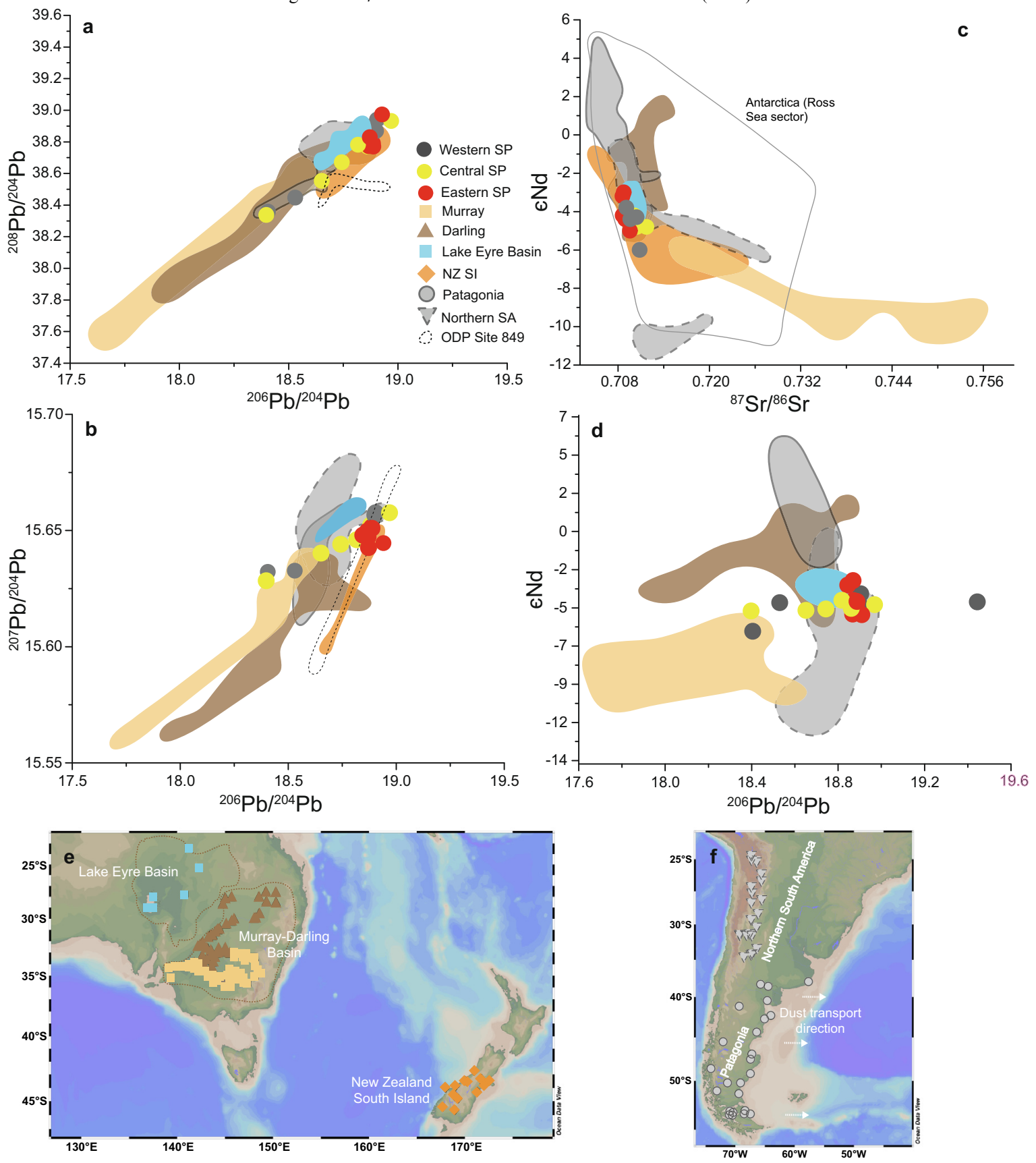

Fig. 8. a-f: Isotopic composition of samples located in northern South American (Northern SA), Patagonian, Australian (Lake Eyre Basin and Murray-Darling Basin) and New Zealand South Island (NZ SI) source areas versus dust samples from the western, central and eastern South Pacific. a and b: Lead isotope results are presented as ${ }^{206} \mathrm{~Pb} /{ }^{204} \mathrm{~Pb}$ versus ${ }^{208} \mathrm{~Pb} /{ }^{204} \mathrm{~Pb}$ and ${ }^{206} \mathrm{~Pb} /{ }^{204} \mathrm{~Pb}$ versus ${ }^{207} \mathrm{~Pb} /{ }^{204} \mathrm{~Pb}$. Dashed black lines show data from Pichat et al. (2014). Northern South America and Patagonia $(<5 \mu \mathrm{m})$ (Gili et al., 2016). Murray-Darling Basin $(<2 \mu \mathrm{m})$ (De Deckker et al., 2010), Lake Eyre Basin $(<5 \mu \mathrm{m})$ (Vallelonga et al., 2010). New Zealand $(<5 \mu \mathrm{m})$ (Vallelonga et al., 2010). c: $\varepsilon N d$ versus ${ }^{87} \mathrm{Sr} /{ }^{86} \mathrm{Sr}$ ratios. d: $\varepsilon \mathrm{Nd}$ versus ${ }^{206} \mathrm{~Pb} /{ }^{204} \mathrm{~Pb}$ ratios. Note that coupled $\varepsilon \mathrm{Nd}$ and ${ }^{206} \mathrm{~Pb} /{ }^{204} \mathrm{~Pb}$ ratios are not available for New Zealand. Northern South America and Patagonia $(<5 \mu \mathrm{m})$ (Gili et al., 2017) and additional PSA data from Patagonia $(<5 \mu \mathrm{m})$ (Delmonte et al., 2004; Sugden et al., 2009). Murray-Darling Basin $(<2 \mu \mathrm{m})$ (Gingele and De Deckker, 2005), Lake Eyre Basin $(<5 \mu \mathrm{m})$ (Revel-Rolland et al., 2006), New Zealand South Island $(<5 \mu \mathrm{m})$ (Delmonte et al., 2004). e: Map of Australia and New Zealand with PSAs. f: Map of southern South America with PSAs. The maps were generated using the Ocean Data View software (Schlitzer, 2015). The color code of the South Pacific dust refers to the core locations shown Fig. 3c. The color and symbol code of the source areas refers to Fig. 8e and f. Thin gray polygon in c reveals data from Victoria Land, the McMurdo Sound sector and Dry Valleys of Antarctica $(<5 \mu \mathrm{m})$ (Delmonte et al., 2004; Blakowski et al., 2016). The PSA data from Victoria Land, the McMurdo Sound sector and the Dry Valleys of Antarctica $(<5 \mu \mathrm{m})$ broadly encircle our data in Sr-Nd space. Given the broad variability in Sr-Nd space of the Antarctic data, we exclude this region as a PSA to our South Pacific dust samples. (For interpretation of the references to colour in this figure legend, the reader is referred to the web version of this article.) 

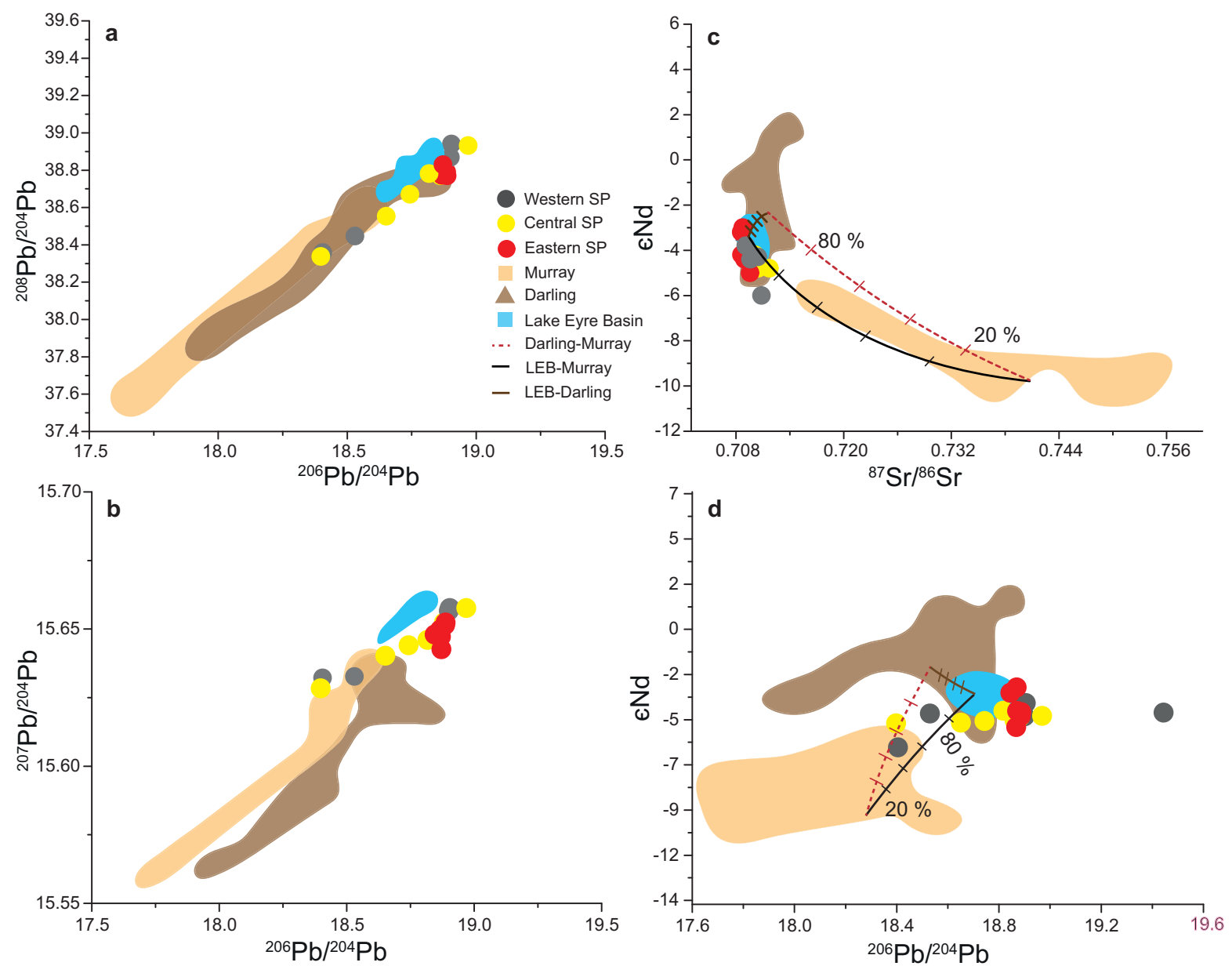

Fig. 9. a-d: Isotopic composition of samples located in Australian (Lake Eyre Basin and Murray-Darling Basin) source areas versus dust samples from the western, central and eastern South Pacific a and $\mathrm{b}$ : Lead isotope results are presented as ${ }^{206} \mathrm{~Pb} /{ }^{204} \mathrm{~Pb}$ versus ${ }^{208} \mathrm{~Pb} /{ }^{204} \mathrm{~Pb}$ and ${ }^{207} \mathrm{~Pb} /{ }^{204} \mathrm{~Pb}$ versus ${ }^{206} \mathrm{~Pb} /{ }^{204} \mathrm{~Pb}$. Murray-Darling Basin $(<2 \mu \mathrm{m})$ (De Deckker et al., 2010), Lake Eyre Basin $(<5 \mu \mathrm{m})($ Vallelonga et al., 2010). c: $\varepsilon N d$ versus ${ }^{87} \mathrm{Sr} /{ }^{86} \mathrm{Sr}$ ratios. d: $\varepsilon N d$ versus ${ }^{206} \mathrm{~Pb} /{ }^{204} \mathrm{~Pb}$ ratios. Murray-Darling Basin $(<2 \mu \mathrm{m})$ (Gingele and De Deckker, 2005), Lake Eyre $(<5$ $\mu \mathrm{m})$ (Revel-Rolland et al., 2006). The color code of the South Pacific dust refers to the core locations shown Fig. 3c. The color and symbol code of the source areas refers to Fig. 8e-f. The mixing trends reveal only mixing approaches because the concentrations and isotopic compositions are not derived from the same samples. Mixing trends were calculated using the REE concentrations from McGowan et al. (2005) for the Lake Eyre Basin (LEB) and from Marx and Kamber (2010) for the Murray-Darling Basin. End-members for radiogenic isotopes were calculated using data from Revel-Rolland et al. (2006) for the Lake Eyre Basin. End-members for radiogenic isotopes for the Murray-Darling Basin are based on data from Gingele and De Dekker (2005). (For interpretation of the references to colour in this figure legend, the reader is referred to the web version of this article.)

and Atlantic sectors of the Southern Ocean (MartínezGarcia et al., 2009; Lamy et al., 2014), it was suggested that iron fertilization in the Southern Ocean was an important driver of the glacial - interglacial change in atmospheric $\mathrm{CO}_{2}$ (80-100 ppmv in total) and likely responsible for an atmospheric $\mathrm{CO}_{2}$ reduction of $\sim 40$ ppmv during late glacial periods (Kohfeld et al., 2005; Martínez-Garcia et al., 2009; Martínez-Garcia et al., 2011). The addition Fe to the Southern Ocean derives from different sources (e.g. dust, icebergs and upwelling). Raiswell et al. (2016) showed that the modern input of bioavailable Fe to the Southern Ocean derived from dust $\left(<1.7 \mathrm{Gt} \mathrm{a}^{-1}\right)$ is considerably lower compared to iceberg derived input (180 to $\left.1400 \mathrm{Gt} \mathrm{a}^{-1}\right)$. The fertilization potential of dust depends on the bioavailability of
$\mathrm{Fe}$, which results from the chemical form of $\mathrm{Fe}$ (Shoenfelt et al., 2017; Shoenfelt et al., 2018). Iron(II), which is mainly produced by glacial physical weathering processes, is more important for the iron fertilization compared to total $\mathrm{Fe}$ (Shoenfelt et al., 2017; Shoenfelt et al., 2018). A recent comparison of $\mathrm{Fe}(\mathrm{II})$ in the Atlantic and Pacific (the used sediment core from the South Pacific is well located in our identified dust area) sectors of the Southern Ocean shows that the $\mathrm{Fe}(\mathrm{II})$ content is distinctly enriched in the Atlantic sector during glacial periods (Shoenfelt et al., 2018). This pattern indicates that Australian dust is likely less bioavailable compared Patagonian dust. Subsequently, Australian dust may have contributed less to the glacial-interglacial $\mathrm{CO}_{2}$ variability. 


\section{CONCLUSION}

We present a comprehensive data set of surface sediment samples, representing terrigenous sedimentation through the Holocene in the Pacific sector of the Southern Ocean. To identify PSAs that deliver dust to the South Pacific, we combine lithogenic fluxes with provenance sensitive proxies ( $\mathrm{REE}$ concentrations, $\mathrm{Sr}, \mathrm{Nd}$ and $\mathrm{Pb}$ isotopes). Lithogenic fluxes provide a general overview of the distribution and different transport mechanisms of terrigenous material into our study area. We observe the highest lithogenic fluxes off New Zealand, which likely indicate a combination of accumulated dust from Australia admixed with riverine input from New Zealand. The sites in the remote open ocean reflect a clear dust signal. Despite geochemical similarities between South Pacific dust and northern South American and Patagonian sources, modern air mass modeling studies in the Southern Hemisphere show that wind trajectories originating in southern South America do not reach our study area. We conclude that the Lake Eyre Basin in central Australia is the most important PSA for atmospheric dust distributed over the South Pacific in the Holocene. However, we acknowledge the possibility of admixture from the Darling area. We emphasize the need for better characterization of PSAs, including the west coast of South America, New Zealand's South Island and Antarctica. Furthermore, provenance analysis in the Atlantic sector of the Southern Ocean is required to better evaluate the contributions from southern South America. These studies will provide the stepping-stones for understanding past variations in atmospheric dust and its link to climate variability.

\section{ACKNOWLEDGEMENTS}

We thank chief scientists, crews and participants of R/V Polarstern (PS35, PS58 and PS75) and R/V Sonne (SO213) cruises for their support. We are grateful to R. Fröhlking-Teichert, S. Wiebe and M. Schulz for providing technical assistance. I. Stimac performed many of the alpha-spectrometric U/Th analyses as initiated by M. R. van der Loeff. I. Stimac also contributed to the mass spectrometric analyses, together with S. Kretschmer. This study is part of the project "Polar Regions and Coasts in the changing Earth System (PACES II)" of the Alfred Wegener Institute (AWI) Helmholtz Centre for Polar and Marine Research. We acknowledge financial support for this work through the AWI and the MARUM-Center for Marine Environmental Sciences, and through the Institute for Chemistry and Biology of the Marine Environment (ICBM) and the Max Planck Institute for Marine Microbiology.

\section{APPENDIX A. SUPPLEMENTARY MATERIAL}

Supplementary data to this article can be found online at https://doi.org/10.1016/j.gca.2019.08.024.

\section{REFERENCES}

Albani S., Delmonte B., Maggi V., Baroni C., Petit J. R., Stenni B., Mazzola C. and Frezzotti M. (2012) Interpreting last glacial to Holocene dust changes at Talos Dome (East Antarctica): implications for atmospheric variations from regional to hemispheric scales. Clim. Past 8, 741-750.

Albani S., Mahowald N. M., Perry A. T., Scanza R. A., Zender C. S., Heavens N. G., Maggi V., Kok J. F. and Otto-Bliesner B. L. (2014) Improved dust representation in the Community Atmosphere Model. J. Adv. Model. Earth Syst. 6, 541-570.

Albarède F., Telouk P., Blichert-Toft J., Boyet M., Agranier A. and Nelson B. (2004) Precise and accurate isotopic measurements using multiple-collector ICPMS. Geochim. Cosmochim. Acta 68, 2725-2744.

Arimoto R. (2001) Eolian dust and climate: relationships to sources, tropospheric chemistry, transport and deposition. Earth-Science Rev. 54, 29-42.

Assmann K. M., Hellmer H. H. and Jacobs S. S. (2005) Amundsen Sea ice production and transport. J. Geophys. Res. Ocean. 110, $1-17$.

Bacon M. P. (1984) Glacial to interglacial changes in carbonate and clay sedimentation in the Atlantic Ocean estimated from ${ }^{230}$ Th measurements. Chem. Geol. 46, 97-111.

Benz V., Esper O., Gersonde R., Lamy F. and Tiedemann R. (2016) Last Glacial Maximum sea surface temperature and seaice extent in the Pacific sector of the Southern Ocean. Quat. Sci. Rev. 146, 216-237.

Blakowski M. A., Aciego S. M., Delmonte B., Baroni C., Salvatore M. C. and Sims K. W. W. (2016) A Sr-Nd-Hf isotope characterization of dust source areas in Victoria Land and the McMurdo Sound sector of Antarctica. Quat. Sci. Rev. 141, 2637.

Blum J. D. and Erel Y. (1997) Rb-Sr isotope systematics of a granitic soil chronosequence: the importance of biotite weathering. Geochim. Cosmochim. Acta 61, 3193-3204.

Blum J. D., Erel Y. and Brown K. (1993) ${ }^{87} \mathrm{Sr} /{ }^{86} \mathrm{Sr}$ ratios of sierra nevada stream waters: implications for relative mineral weathering rates. Geochim. Cosmochim. Acta 57, 5019-5025.

Bollhöfer A. and Rosman K. J. R. (2001) Isotopic source signatures for atmospheric lead: the Northern Hemisphere. Geochim. Cosmochim. Acta 65, 1727-1740.

Bowler J. M. (1976) Aridity in Australia: age, origins and expression in aeolian landforms and sediments. Earth Sci. Rev. 12, 279-310.

Bradtmiller L. I., Anderson R. F., Fleisher M. Q. and Burckle L. H. (2009) Comparing glacial and Holocene opal fluxes in the Pacific sector of the Southern Ocean. Paleoceanography 24, 120.

Brewer P., Nozaki Y., Spencer D. and Fleer A. (1980) Sediment trap experiments in the deep North Atlantic: isotopic and elemental fluxes. J. Mar. Res. 38, 703-728.

Carroll D. and Starky H. C. (1971) Reactivity of clay minerals with acids and alkalies. Clays Clay Miner. 19, 321-335.

Chase Z., Anderson R. F., Fleisher M. Q. and Kubik P. W. (2003) Accumulation of biogenic and lithogenic material in the Pacific sector of the Southern Ocean during the past 40,000 years. Deep Res. Part II Top. Stud. Oceanogr. 50, 799-832.

Cheng H., Lawrence Edwards R., Shen C.-C., Polyak V. J., Asmerom Y., Woodhead J., Hellstrom J., Wang Y., Kong X., Spötl C., Wang X. and Calvin Alexander E. (2013) Improvements in ${ }^{230} \mathrm{Th}$ dating, ${ }^{230} \mathrm{Th}$ and ${ }^{234} \mathrm{U}$ half-life values, and $\mathrm{U}$ Th isotopic measurements by multi-collector inductively coupled plasma mass spectrometry. Earth Planet. Sci. Lett. 371372, 82-91.

Dasch E. J. (1969) Strontium isotopes in weathering profiles, deepsea sediments, and sedimentary rocks. Geochim. Cosmochim. Acta 33, 1521-1552.

De Deckker P., Norman M., Goodwin I. D., Wain A. and Gingele F. X. (2010) Lead isotopic evidence for an Australian source of 
aeolian dust to Antarctica at times over the last 170,000 years. Palaeogeogr. Palaeoclimatol. Palaeoecol. 285, 205-223.

Delmonte B., Basile-Doelsch I., Petit J.-R., Maggi V., RevelRolland M., Michard A., Jagoutz E. and Grousset F. (2004) Comparing the Epica and Vostok dust records during the last 220,000 years: stratigraphical correlation and provenance in glacial periods. Earth-Science Rev. 66, 63-87.

Delmonte B., Paleari C. I., Andò S., Garzanti E., Andersson P. S., Petit J. R., Crosta X., Narcisi B., Baroni C., Salvatore M. C., Baccolo G. and Maggi V. (2017) Causes of dust size variability in central East Antarctica (Dome B): Atmospheric transport from expanded South American sources during Marine Isotope Stage 2. Quat. Sci. Rev. 168, 55-68.

Eden D. N. and Hammond A. P. (2003) Dust accumulation in the New Zealand region since the last glacial maximum. Quat. Sci. Rev. 22, 2037-2052.

Eglinton G. and Hamilton R. J. (1967) Leaf epicuticular waxes. Science 156, 1322-1335.

Eglinton T. I. and Eglinton G. (2008) Molecular proxies for paleoclimatology. Earth Planet. Sci. Lett. 275, 1-16.

Ekström M., Mctainsh G. H. and Chappell A. (2004) Australian dust storms: temporal trends and relationships with synoptic pressure distributions (1960-99). Int. J. Climatol. 24, 15811599.

Esper O., Gersonde R. and Kadagies N. (2010) Diatom distribution in southeastern Pacific surface sediments and their relationship to modern environmental variables. Palaeogeogr. Palaeoclimatol. Palaeoecol. 287, 1-27.

Feng J. L., Hu Z. G., Ju J. T. and Zhu L. P. (2011) Variations in trace element (including rare earth element) concentrations with grain sizes in loess and their implications for tracing the provenance of eolian deposits. Quat. Int. 236, 116-126.

Francois R., Frank M., Rutgers van der Loeff M. M. and Bacon M. P. (2004) ${ }^{230}$ Th normalization: An essential tool for interpreting sedimentary fluxes during the late Quaternary. Paleoceanography 19.

Frank M. (2002) Radiogenic isotopes: tracers of past ocean circulation and erosional input. Rev. Geophys. 40, 1-38.

Galer S. J. G. and Abouchami W. (1998) Practical application of lead triple spiking for correction of instrumental mass discrimination. Mineral. Mag. 62A, 491-492.

Geibert W., Rutgers van der Loeff M. M., Usbeck R., Gersonde R., Kuhn G. and Seeberg-Elverfeldt J. (2005) Quantifying the opal belt in the Atlantic and southeast Pacific sector of the Southern Ocean by means of ${ }^{230} \mathrm{Th}$ normalization. Global Biogeochem, Cycles, p. 19.

Gersonde R. (1995) The Expedition of the Research Vessel "Polarstern" to the Southeast Pacific in 1995 (ANT-XII/4), Reports on Polar and Marine Research, Bremerhaven, Alfred Wegener Institute for Polar and Marine Research.

Gersonde R. (2001) The Expedition of the Research Vessel "Polarstern" to the South Pacific in 2001 (ANT-XVIII/5a), Reports on Polar and Marine Research, Bremerhaven, Alfred Wegener Institute for Polar and Marine Research.

Gersonde R. (2011) The Expedition of the Research Vessel "Polarstern" to the polar South Pacific in 2009/2010 (ANTXXXVI/2-BIPOMAC), Reports on Polar and Marine Research, Bremerhaven, Alfred Wegener Institute for Polar and Marine Research. 632, 330.

Gili S., Gaiero D. M., Goldstein S. L., Chemale F., Koester E., Jweda J., Vallelonga P. and Kaplan M. R. (2016) Provenance of dust to Antarctica: a lead isotopic perspective. Geophys. Res. Lett. 43, 2291-2298.

Gili S., Gaiero D. M., Goldstein S. L., Chemale F., Jweda J., Kaplan M. R., Becchio R. A. and Koester E. (2017) Glacial/ interglacial changes of Southern Hemisphere wind circulation from the geochemistry of South American dust. Earth Planet. Sci. Lett. 469, 98-109.

Gingele F. X. and De Deckker P. (2005) Clay mineral, geochemical and $\mathrm{Sr}-\mathrm{Nd}$ isotopic fingerprinting of sediments in the MurrayDarling fluvial system, southeast Australia. Aust. J. Earth Sci. 52, 965-974.

Ginoux P., Prospero J. M., Gill T. E., Hsu N. C. and Zhao M. (2012) Global-scale attribution of anthropogenic and natural dust sources and their emission rates based on MODIS Deep Blue aerosol products. Rev. Geophys. 50.

Goldstein S. L., O’Nions R. K. and Hamilton P. J. (1984) A Sm$\mathrm{Nd}$ isotopic study of atmospheric dusts and particulates from major river systems. Earth Planet. Sci. Lett. 70, 221-236.

Grousset F. E. and Biscaye P. E. (2005) Tracing dust sources and transport patterns using $\mathrm{Sr}, \mathrm{Nd}$ and $\mathrm{Pb}$ isotopes. Chem. Geol. 222, 149-167.

Henderson G. M. and Anderson R. F. (2003) The U-series toolbox for paleoceanography. Rev. Mineral. Geochemistry 52, 493-531.

Hesse P. P. (1994) The record of continental dust in Tasman Sea sediments. Quat. Sci. Rev. 13, 257-272.

Hesse P. P. and McTainsh G. H. (2003) Australian dust deposits: modern processes and the Quaternary record. Quat. Sci. Rev. 22, 2007-2035.

Hillenbrand C. D. (2000) Glaciomarine sedimentation on the continental margins of the Amundsen and Bellingshausen Seas, West Antarctica-indications for paleoenvironmental changes during the Quaternary climatic cycles. Reports Polar Res. 346, 182.

Honda M., Yabuki S. and Shimizu H. (2004) Geochemical and isotopic studies of aeolian sediments in China. Sedimentology 51, 211-230.

Horwitz E. P., Dietz M. L. and Chiarizia R. (1992) A novel strontium-selective extraction chromatographic resin. Solvent Extr. Ion Exch. 10, 313-336.

Jacobsen S. B. and Wasserburg G. J. (1980) Sm-Nd isotopic evolution of chondrites. Earth Planet. Sci. Lett. 50, 139-155.

Jaeschke A., Wengler M., Hefter J., Ronge T. A., Geibert W., Mollenhauer G., Gersonde R. and Lamy F. (2017) A biomarker perspective on dust, productivity, and sea surface temperature in the Pacific sector of the Southern Ocean. Geochim. Cosmochim. Acta 204, 120-139.

Jickells T. D., An Z. S., Andersen K. K., Baker A. R., Bergametti G., Brooks N., Cao J. J., Boyd P. W., Duce R. A., Hunter K. A., Kawahata H., Kubilay N., LaRoche J., Liss P. S., Mahowald N., Prospero J. M., Ridgwell A. J., Tegen I. and Torres R. (2005) Global iron connections between desert dust, ocean biogeochemistry, and climate. Science 308, 67-71.

Jouzel J., Masson-Delmotte V., Cattani O., Dreyfus G., Falourd S., Hoffmann G., Minster B., Nouet J., Barnola J. M., Chappellaz J., Fischer H., Gallet J. C., Johnsen S., Leuenberger M., Loulergue L., Luethi D., Oerter H., Parrenin F., Raisbeck G., Raynaud D., Schilt A., Schwander J., Selmo E., Souchez R., Spahni R., Stauffer B., Steffensen J. P., Stenni B., Stocker T. F., Tison J. L., Werner M. and Wolff E. W. (2007) Orbital and millennial antarctic climate variability over the past 800,000 years. Science 317, 793-796.

Jweda J., Bolge L., Class C. and Goldstein S. L. (2016) High precision $\mathrm{Sr}-\mathrm{Nd}-\mathrm{Hf}-\mathrm{Pb}$ isotopic compositions of USGS reference material BCR-2. Geostand. Geoanalytical Res. 40, 101-115.

Kamber B. S., Marx S. K. and McGowan H. A. (2010) Comment on "Lead isotopic evidence for an Australian source of Aeolian dust to Antarctica at times over the last 170,000 years" by P. De Deckker, M. Norman, I.D. Goodwin, A. Wain and F.X. Gingele. Palaeogeogr. Palaeoclimatol. Palaeoecol. 298, 432-436.

Kanayama S., Yabuki S., Zeng F., Liu M., Shen Z., Liu L., Yanagisawa F. and Abe O. (2005) Size-Dependent Geochem- 
ical Characteristics of Asian Dust. J. Meteorol. Soc. Japan. Ser. II 83A, 107-120.

Kohfeld K. E. and Harrison S. P. (2001) DIRTMAP: The geological record of dust. Earth-Science Rev. 54, 81-114.

Kohfeld K. E., Le Quéré C., Harrison S. P. and Anderson R. F. (2005) Role of Marine Biology in Glacial-Interglacial CO2 Cycles. Science 308, 74-78.

Lambert F., Bigler M., Steffensen J. P., Hutterli M. and Fischer H. (2012) Centennial mineral dust variability in high-resolution ice core data from Dome C, Antarctica. Clim. Past 8, 609-623.

Lambert F., Delmonte B., Petit J. R., Bigler M., Kaufmann P. R., Hutterli M. A., Stocker T. F., Ruth U., Steffensen J. P. and Maggi V. (2008) Dust-climate couplings over the past 800,000 years from the EPICA Dome C ice core. Nature 452, 616-619.

Lamy F. (2016) The Expedition PS97 of the Research Vessel POLARSTERN to the Drake Passage in 2016, Reports on polar and marine research, Bremerhaven. Alfred Wegener Institute for Polar and Marine Research 701, 571.

Lamy F., Gersonde R., Winckler G., Esper O., Jaeschke A., Kuhn G., Ullermann J., Martinez-Garcia A., Lambert F. and Kilian R. (2014) Increased dust deposition in the pacific southern ocean during glacial periods. Science 343, 403-407.

Li F., Ginoux P. and Ramaswamy V. (2008) Distribution, transport, and deposition of mineral dust in the Southern Ocean and Antarctica: contribution of major sources. $J$. Geophys. Res. Atmos. 113, 1-15.

Lugmair G. W. and Galer S. J. G. (1992) Age and isotopic relationships among the angrites Lewis Cliff 86010 and Angra dos Reis. Geochim. Cosmochim. Acta 56, 1673-1694.

Lüthi D., Le Floch M., Bereiter B., Blunier T., Barnola J.-M., Siegenthaler U., Raynaud D., Jouzel J., Fischer H., Kawamura K. and Stocker T. F. (2008) High-resolution carbon dioxide concentration record $650,000-800,000$ years before present. Nature 453, 379.

Maher B. A., Prospero J. M., Mackie D., Gaiero D., Hesse P. P. and Balkanski Y. (2010) Global connections between aeolian dust, climate and ocean biogeochemistry at the present day and at the last glacial maximum. Earth-Science Rev. 99, 61-97.

Mahowald N. M., Muhs D. R., Levis S., Rasch P. J., Yoshioka M., Zender C. S. and Luo C. (2006) Change in atmospheric mineral aerosols in response to climate: Last glacial period, preindustrial, modern, and doubled carbon dioxide climates. J. Geophys. Res. Atmos. 111.

Martin J. H. (1990) Glacial-interglacial CO2 change: the Iron Hypothesis. Paleoceanography 5, 1-13.

Martínez-Garcia A., Rosell-Melé A., Geibert W., Gersonde R., Masqué P., Gaspari V. and Barbante C. (2009) Links between iron supply, marine productivity, sea surface temperature, and $\mathrm{CO} 2$ over the last 1.1 Ma. Paleoceanography 24, 1-14.

Martínez-Garcia A., Rosell-Melé A., Jaccard S. L., Geibert W., Sigman D. M. and Haug G. H. (2011) Southern Ocean dust-climate coupling over the past four million years. Nature 476, 312-315.

Martínez-García A., Sigman D. M., Ren H., Anderson R. F., Straub M., Hodell D. A., Jaccard S. L., Eglinton T. I. and Haug G. H. (2014) Iron fertilization of the subantarctic ocean during the last ice age. Science 343, 1347-1350.

Marx S. K. and Kamber B. S. (2010) Trace-element systematics of sediments in the Murray-Darling Basin, Australia: sediment provenance and palaeoclimate implications of fine scale chemical heterogeneity. Appl. Geochemistry 25, 1221-1237.

Marx S. K., Kamber B. S. and McGowan H. A. (2005) Provenance of long-travelled dust determined with ultra-trace-element composition: a pilot study with samples from New Zealand glaciers. Earth Surf. Process. Landforms 30, 699-716.

McCave I. N., Manighetti B. and Robinson S. G. (1995) Sortable silt and fine sediment size/composition slicing: parameters for palaeocurrent speed and palaeoceanography. Paleoceanography 10, 593-610.

McGowan H. A., Kamber B., McTainsh G. H. and Marx S. K. (2005) High resolution provenancing of long travelled dust deposited on the Southern Alps, New Zealand. Geomorphology 69, 208-221.

McGowan H. and Clark A. (2008) Identification of dust transport pathways from Lake Eyre, Australia using Hysplit. Atmos. Environ. 42, 6915-6925.

McTainsh G. H. (1989) Quaternary aeolian dust processes and sediments in the Australian region. Quat. Sci. Rev. 8, 235-253.

Meyer I., Davies G. R. and Stuut J. B. W. (2011) Grain size control on $\mathrm{Sr}-\mathrm{Nd}$ isotope provenance studies and impact on paleoclimate reconstructions: an example from deep-sea sediments offshore NW Africa. Geochemistry, Geophys. Geosystems 12.

Neff P. D. and Bertler N. A. N. (2015) Trajectory modeling of modern dust transport to the Southern Ocean and Antarctica. J. Geophys. Res. Atmos. 120, 9303-9322.

Orsi A. H., Whitworth T. and Nowlin W. D. (1995) On the meridional extent and fronts of the Antarctic Circumpolar Current. Deep. Res. 42, 641-673.

Pichat S., Abouchami W. and Galer S. J. G. (2014) Lead isotopes in the Eastern Equatorial Pacific record Quaternary migration of the South Westerlies. Earth Planet. Sci. Lett. 388, 293-305.

Pin C. and Zalduegui J. S. (1997) Sequential separation of light rare-earth elements, thorium and uranium by miniaturized extraction chromatography: application to isotopic analyses of silicate rocks. Anal. Chim. Acta 339, 79-89.

Prospero J. M., Ginoux P., Torres O., Nicholson S. and Gill T. E. (2002) Environmental characterization of global sources of atmospheric soil dust identified with the NIMBUS 7 Total Ozone Mapping Spectrometer (TOMS) absorbing aerosol product. Rev. Geophys. 40, 1-31.

Raiswell R., Hawkings J. R., Benning L. G., Baker A. R., Death R., Albani S., Mahowald N., Krom M. D., Poulton S. W., Wadham J. and Tranter M. (2016) Potentially bioavailable iron delivery by iceberg-hosted sediments and atmospheric dust to the polar oceans. Biogeosciences 13, 3887-3900.

Rebesco M., Larter R. D., Camerlenghi A. and Barker P. F. (1996) Giant sediment drifts on the continental rise west of the Antarctic Peninsula. Geo-Marine Lett. 16, 65-75.

Revel-Rolland M., De Deckker P., Delmonte B., Hesse P., Magee J., Basile-Doelsch I., Grousset F. and Bosch D. (2006) Eastern Australia: a possible source of dust in East Antarctica interglacial ice. Earth Planet. Sci. Lett. 249, 1-13.

Sassen K., DeMott P. J., Prospero J. M. and Poellot M. R. (2003) Saharan dust storms and indirect aerosol effects on clouds: CRYSTAL-FACE results. Geophys. Res. Lett. 30, 1-4.

Schlitzer R. (2015) Ocean Data View. http://odv.awi.de.

Shoenfelt E. M., Sun J., Winckler G., Kaplan M. R., Borunda A. L., Farrell K. R., Moreno P. I., Gaiero D. M., Recasens C., Sambrotto R. N. and Bostick B. C. (2017) High particulate iron (II) content in glacially sourced dusts enhances productivity of a model diatom. Sci. Adv. 3.

Shoenfelt E. M., Winckler G., Lamy F., Anderson R. F. and Bostick B. C. (2018) Highly bioavailable dust-borne iron delivered to the Southern Ocean during glacial periods. Proc. Natl. Acad. Sci. 115, 11180-11185.

Strelow F. W. E. (1960) An ion exchange selectivity scale of cations based on equilibrium distribution coefficients. Anal. Chem. 32, $1185-1188$.

Struve T., Van De Flierdt T., Robinson L. F., Bradtmiller L. I., Hines S. K., Adkins J. F., Lambelet M., Crocket K. C., Kreissig K., Coles B. and Auro M. E. (2016) Neodymium isotope analyses after combined extraction of actinide and lanthanide 
elements from seawater and deep-sea coral aragonite. Geochem. Geophys. Geosyst. 17, 232-240.

Sugden D. E., McCulloch R. D., Bory A. J.-M. and Hein A. S. (2009) Influence of Patagonian glaciers on Antarctic dust deposition during the last glacial period. Nat. Geosci 2, 281285.

Tanaka T., Togashi S., Kamioka H., Amakawa H., Kagami H., Hamamoto T., Yuhara M., Orihashi Y., Yoneda S., Shimizu H., Kunimaru T., Takahashi K., Yanagi T., Nakano T., Fujimaki H., Shinjo R., Asahara Y., Tanimizu M. and Dragusanu C. (2000) JNdi-1: a neodymium isotopic reference in consistency with LaJolla neodymium. Chem. Geol. 168, 279281.

Tanaka T. Y. and Chiba M. (2006) A numerical study of the contributions of dust source regions to the global dust budget. Glob. Planet. Change 52, 88-104.

Taylor S. R. and McLennan S. M. (1995) The geochemical evolution of the continental crust. Rev. Geophys. 33, 241-265.

Tegen I. and Fung I. (1994) Modeling of mineral dust in the atmosphere: sources, transport, and optical thickness. $J$. Geophys. Res. 99, 22897-22914.

Thirlwall M. F. (1991) Long-term reproducibility of multicollector $\mathrm{Sr}$ and $\mathrm{Nd}$ isotope ratio analysis. Chem. Geol. Isot. Geosci. Sect. 94, 85-104.

Thomson J., Colley S., Anderson R., Cook G. T., MacKenzie A. B. and Harkness D. D. (1993) Holocene sediment fluxes in the northeast Atlantic from $230 \mathrm{Th}$ excess and radiocarbon measurements. Paleoceanography 8, 631-650.
Tiedemann R. (2012) FS Sonne Fahrtbericht / Cruise Report SO213. Alfred Wegener Institute, Bremerhaven.

Tournadre J., Girard-Ardhuin F. and Legrésy B. (2012) Antarctic icebergs distributions, 2002-2010. J. Geophys. Res. C Ocean. 117, 2002-2010.

Tsoar H. and Pye K. (1987) Dust transport and the question of desert loess formation. Sedimentology 34, 139-153.

Vallelonga P., Gabrielli P., Balliana E., Wegner A., Delmonte B., Turetta C., Burton G., Vanhaecke F., Rosman K. J. R., Hong S., Boutron C. F., Cescon P. and Barbante C. (2010) Lead isotopic compositions in the EPICA Dome $\mathrm{C}$ ice core and Southern Hemisphere Potential Source Areas. Quat. Sci. Rev. 29, 247-255.

Walter H. J., Rutgers van der Loeff M. M. and Hoeltzen H. (1997) Enhanced scavenging of ${ }^{231} \mathrm{~Pa}$ relative to ${ }^{230} \mathrm{Th}$ in the South Atlantic south of the Polar Front: implications for the use of the ${ }^{231} \mathrm{~Pa} /{ }^{230} \mathrm{Th}$ ratio as a paleoproductivity proxy. Earth Planet. Sci. Lett. 149, 85-100.

Weis D., Kieffer B., Maerschalk C., Barling J., de Jong J., Williams G. A., Hanano D., Pretorius W., Mattielli N., Scoates J. S., Goolaerts A., Friedman R. M. and Mahoney J. B. (2006) Highprecision isotopic characterization of USGS reference materials by TIMS and MC-ICP-MS. Geochemistry, Geophys. Geosystems 7. 